IZA DP No. 6226

Transnational Trafficking, Law Enforcement and Victim Protection:

A Middleman Trafficker's Perspective

Randall Akee

Arjun Bedi

Arnab K. Basu

Nancy H. Chau

December 2011 


\title{
Transnational Trafficking, Law Enforcement and Victim Protection: A Middleman Trafficker's Perspective
}

\author{
Randall Akee \\ Tufts University and IZA \\ Arjun Bedi \\ ISS, Erasmus University Rotterdam and IZA \\ Arnab K. Basu \\ College of William \& Mary, ZEF and IZA \\ Nancy H. Chau \\ Cornell University, ZEF and IZA \\ Discussion Paper No. 6226 \\ December 2011 \\ IZA \\ P.O. Box 7240 \\ 53072 Bonn \\ Germany \\ Phone: +49-228-3894-0 \\ Fax: +49-228-3894-180 \\ E-mail: iza@iza.org
}

Any opinions expressed here are those of the author(s) and not those of IZA. Research published in this series may include views on policy, but the institute itself takes no institutional policy positions.

The Institute for the Study of Labor (IZA) in Bonn is a local and virtual international research center and a place of communication between science, politics and business. IZA is an independent nonprofit organization supported by Deutsche Post Foundation. The center is associated with the University of Bonn and offers a stimulating research environment through its international network, workshops and conferences, data service, project support, research visits and doctoral program. IZA engages in (i) original and internationally competitive research in all fields of labor economics, (ii) development of policy concepts, and (iii) dissemination of research results and concepts to the interested public.

IZA Discussion Papers often represent preliminary work and are circulated to encourage discussion. Citation of such a paper should account for its provisional character. A revised version may be available directly from the author. 


\section{ABSTRACT \\ Transnational Trafficking, Law Enforcement and Victim Protection: A Middleman Trafficker's Perspective*}

We explore three hitherto poorly understood characteristics of the human trafficking market the cross-border ease of mobility of traffickers, the relative bargaining strength of traffickers and final buyers, and the elasticity of buyers' demand. In a model of two-way bargaining, the exact configuration of these characteristics is shown to determine whether domestic and foreign crackdowns on illicit employment mutually reinforce or counteract one another in efforts to stem the tide of trafficking. Estimation results from a gravity model of trafficking present evidence consistent with the mutual reinforcement view, indicating considerable ease of mobility, partial bargaining power, and inelastic demand.

JEL Classification: K42, R23, O15

Keywords: $\quad$ human trafficking, two-way Nash bargaining, victim protection, law enforcement

Corresponding author:

Randall Akee

Tufts University

Department of Economics

8 Upper Campus Road, Braker 114B

Medford, MA 02155

USA

E-mail: randall.akee@tufts.edu

\footnotetext{
* For suggestions and comments on earlier versions of this paper, we thank Enrico Spolaore, Sugata Marjit, Jyotsna Jalan, Stephan Klonner, Keith Maskus, Xiaobo Zhang and seminar participants at the Allied Social Science Meetings, Alexander von Humboldt Network Meeting, School of Advanced Social Sciences - Johns Hopkins University, IFPRI, International Economics Finance Society Meeting, Final Conference of the Transnationality of Migrants Network, IZA Conference on Illegal and Illicit Migration, Institute of Social Studies-The Hague, Poverty, Equity and Growth Network Conference, Fourth Annual Conference on Development and Institutions - Brunel University, Center for the Study of Social Sciences - Kolkata, University of Hannover and the College of William and Mary. Financial support from the Alexander von Humboldt Foundation is gratefully acknowledged.
} 


\section{Introduction}

Transnational human trafficking is one of the least studied forms of international movement in persons. But what little is known about it suggests that it is a highly lucrative business. A recent ILO report puts the total illicit profits produced each year by trafficked laborers at US $\$ 31.7$ billion, and the estimated stock of forced labor due to trafficking at 2.45 million (ILO 2005). Together these figures imply a level of illicit profits per trafficked person per year at close to US $\$ 13,000$. An overwhelming majority of trafficked persons are women and girls, and sexual exploitation is the most commonly identified form of profiteering on trafficked persons (US Department of State 2009). ${ }^{1}$ Matching worldwide demand with victims in this global trade in humans, recent research shows that the perpetrators of trafficking are driven primarily by local criminal networks in source countries (UNODC 2009). This latest evidence based on painstakingly collected criminal justice data worldwide reveal that some local networks in the source countries sell victims domestically to feed domestic illicit demand, while others are directed internationally instead to service criminal networks in destination countries, where diaspora population from the same source country are frequently used as conduits.

These salient features of the market for illicit trade in humans uncovered to date - buyers' demand driven exploitative employment that operates underground, and footloose middleman traffickers with multiple possible buyer sources reaching across national borders - reveal two critical though hitherto poorly understood sets of issues related to trafficking policy design. First, with possibly competing demand for trafficked victims coming from both domestic and foreign sources, how effective is a stand alone crackdown on domestic illicit activities that acts on domestic buyers' willingness to pay, but leaves foreign demand untouched? Conversely what about stricter foreign law enforcement, or victim protection programs such as an amnesty that facilitate discovery by law enforcement in destination countries?

Next, the clandestine nature of the employment of trafficked victims and the need to evade law enforcement are conditions that foster underground bargaining and exchange rather than open

\footnotetext{
${ }^{1}$ The exploitative and involuntary nature of the employment, where the victims take no part of the illicit profit, squarely sets human trafficking apart from voluntary migration and human smuggling. Specifically, the Protocol to Prevent, Suppress and Punish Trafficking in Persons, especially Women and Children defines the crime of trafficking in human beings to mean "the recruitment, transportation, transfer, harbouring or receipt of persons, by means of the threat or use of force or other forms of coercion, of abduction, of fraud, of deception, of the abuse of power or of a position of vulnerability or of the giving or receiving of payments or benefits to achieve the consent of a person having control over another person, for the purpose of exploitation".
} 
competition for the labor of victims. But the mere possibility of a departure from the competitive frame means that the trafficker may no longer partake in the full measure of buyers' willingness to pay. Now the same set of questions concerning the effectiveness of a crackdown on illicit activities take on sharply different meaning, for what is the trafficking impact of a crackdown on illicit activities in the source country if the bargaining position of footloose transnational traffickers hinges on a threat to switch to a domestic buyer source? Similarly, what about the case when there is a similar hike in the likelihood of discovery in the foreign country?

These are the questions that guide the tasks set forth in this paper. Our goal is to contribute to the debate on the choice and coordination of international efforts to curb transnational trafficking, by means of legislation that directly act on the demand side incentives of middlemen to engage in trafficking. The issue is of vital importance for a number of reasons. As set out in the UN Protocol to Prevent, Suppress and Punish Trafficking in Persons, signatory governments agree to adopt legislative measures to discourage the demand that fosters the exploitation of persons that leads to trafficking. But whether a heightened likelihood of discovery in illicit service sectors can in fact achieve this goal, and stem the tide of transnational trafficking is a matter of vigorous debate. The Trafficking in Persons report (U.S. Department of State 2007) discusses the view in favor of a crackdown on prostitution as follows:

"Sex trafficking would not exist without the demand for commercial sex flourishing around the world. The U.S. Government adopted a strong position against prostitution in a December 2002 policy decision, which states that prostitution is inherently harmful and dehumanizing and fuels trafficking in persons. (pp. 27.)"

In sharp contrast, the Trafficking in Human Beings report of the Dutch National Rapporteur (Bureau of the Dutch National Rapporteur on Trafficking 2005) notes:

"Opponents of the criminalisation of prostitution take the view that it is precisely this that plays into the hands of the criminal networks... They feel that prostitution would continue regardless, while at the same time sex workers would be stigmatised, criminalised or - because their clients could be prosecuted - marginalised because of a repressive approach. (pp.7)".

To date, the question of how victim protection and empowerment, as well as law enforcement 
against illicit activities ultimately impact traffickers' incentives remains largely open due to a real paucity in both theoretical and empirical research in the literature.

Apart from illicit trade in humans, the issues addressed here share many parallels with other forms of illicit international trade in goods such as drugs, endangered species, and arms, for example, and many of the lessons learned here for the case of trafficking can be more broadly applied to alternative forms of of illicit international trade. Closely related to our work, Becker, Grossman and Murphy (2006) examines the effectiveness of law enforcement on the volume of illicit drug activities in a competitive setting within a single country, and highlights the importance of the elasticity of demand in determining the answer. Our analysis builds on and substantially adds to the theoretical insights developed therein, and does so (i) theoretically by proposing a two-way bargaining framework that enables us to better understand the negotiation problem of a footloose trafficker, and (ii) empirically by putting together a novel dataset that enables us to test the implications of the model.

In the model, trafficking arises first and foremost as a consequence of middleman traffickers' response to buyers' willingness to pay in the source and the host countries. This willingness to pay is taken to be endogenous, depending among other things on the likelihood of discovery and work stoppage. We envisage two sets of policies as key determinants of these likelihoods: (i) victim protection programs, such as an amnesty granted to trafficked victims, and (ii) law enforcement against prostitution. The former raises the likelihood of work stoppage by empowering victims to access host country police authorities, and the latter achieves similar ends through direct law enforcement.

Beyond willingness to pay, we pay particular attention to the possible implications of the underground transaction between a trafficker and a buyer, domestic or foreign. We do so by expressing a footloose trafficker's decision problem as a two-way bilateral Nash bargaining problem, in which we allow for (i) a full range of possible relative bargaining strengths of the trafficker in both the source and the foreign countries, and (ii) heterogeneity among traffickers in their ability to switch between a domestic and a foreign buyer in the form of a search cost. Does a hike in the likelihood of discovery on source country illicit activities offset or reinforce the trafficking impact of a similar crackdown in the foreign country?

Consistent with the message of Becker, Grossman and Murphy (2006), we find that if buyer 
demand is inelastic, an increase in the likelihood of discovery in the destination country will raise buyers' willingness to pay there, thus encouraging the inflow of trafficked victims. By contrast, an increase in the likelihood of discovery in the source country will instead raise source country buyer's willingness to pay, thus discouraging the outflow of trafficked victims. A priori, therefore, source and destination crackdowns on illicit activities should be expected to have polar opposite impacts on the incidence of transnational trafficking, so long as middleman traffickers are expected to reap the full value of the buyer's willingness to pay in the destination and in the source country.

While integral, this is but a part of the story. Indeed, in our two-way bargaining setup, the expected profit of a footloose trafficker in the source country is shown to depend on his threat point income - the expected profit of the same victim in the destination country, and vice versa. Thus, we address the issue of the simultaneous endogeneity of the traffickers' threat point bargaining positions both at home and abroad, depending jointly on the configuration of host and source country policies on illicit employment and victim protections.

The resulting setup illustrates clearly why international policy coordination in the presence of footloose traffickers can present a genuine challenge, requiring detailed information not just on demand elasticity, but critically also on the the bargaining strength and cross-border reach of the traffickers. Indeed, we conclude our theoretical analysis by displaying altogether sixteen distinctive configurations of market characteristics combinations wherein the effectiveness of source and host policies on trafficking can potentially raise, decrease, counteract, or mutually reinforce each other. This allows for a systematic analysis of the rationale behind each configuration of policy effectiveness. But more importantly, this also showcases an hitherto under-appreciated link between policy effectiveness and the characteristics of the market for trafficking. For example, we show that source and host country law enforcement mutually reinforce each other in increasing the transnational flow of trafficked victims only in the presence of the following combination of market characteristics: traffickers who enjoyable considerable cross-border mobility but partial bargaining strength, and a sufficiently inelastic buyer demand.

The empirical part of the paper accordingly takes these issues to the data, and employs a novel $187 \times 187$ matrix of the incidence of bilateral international trafficking collected for the purpose of this research (Basu and Chau 2008). We estimate a modified gravity model of international trafficking, and in so doing we simultaneously account for the push and pull forces of international 
trafficking in determining the bilateral match between host and destination countries. We augment a standard gravity model of international migration by including a measure of host country granting of legal amnesty to discovered victims of trafficking. After controlling for potential unobserved heterogeneity and endogeneity based on a two-stage least squares regression, we find that countries which grant legal amnesty to immigrants have an increased likelihood of experiencing human trafficking. This empirical finding is robust to the use of several different instruments. We also include prostitution laws in the host and the source countries in our estimation. Based on our theoretical model, these empirical results are consistent with (i) inelastic final buyers' demand and (ii) partial bargaining power on the part of traffickers and (iii) considerable cross-border reach in traffickers' ability to identify buyers.

Our modified gravity approach introduces a new dimension to a very small, but growing literature on the empirics of trafficking in humans. These studies have empirically examined the pattern of trafficking, using distinctive measures such as country level indicators respectively of "out-trafficking" and "in-trafficking" (Bales 1999, Danilova-Tranior and Belser 2006), the incidence of forced labor in illicit sectors to which trafficking in persons belong as a subset (Busse and Braun 2002), and data from surveys of victims and families (Mahmoud and Trebesch 2010). These studies single out a list of factors that are associated with trafficking: socio-economic and governance indicators in both host and source countries such as poverty, unemployment and government corruption; the practice of migration for work in the source country; as well as trade and foreign direct investment linkages. Clearly, much more remains to be uncovered concerning the sources in particular of a bilateral match between source and destination countries of trafficking, and the role of source and destination country legislation directed towards the illicit sectors where victims are ultimately employed.

A theoretical literature on the more general issue of exploitative labor and intermediaries assisted migration also exists but is substantially thinner. Most closely related to our work dealing with trafficking policy formation, Rogers and Swinnerton (2008) provides theoretical justification for a complete ban on exploitative labor, where employment is made possible only by the deception of firms concerning the true nature of work. Friebel and Guriev (2006) examines the role of deportation policies on debt-financed illegal immigration in an innovative model where wealth constrained individuals repay their debt to smugglers by entering into servitude contracts, and 
where such servitude contracts are easier to enforce in illicit sectors of employment. They show the intriguing result that stricter border controls can in fact increase debt financed migration as smugglers respond to policy-induced change in the market value of a migrant by adjusting the volume of smuggling. Our paper contributes to this growing literature by introducing a two-country setup in which both domestic and transnational trafficking are in the trafficker's choice set, and where the impact of legislation is shown to interact in important ways with the market structure in which traffickers operate.

\section{The Basic Model}

We consider a setting featuring the interactions between a buyer of the services of trafficked victims and a middleman trafficker. Potential buyers originate from two sources, the domestic (source) country illicit sector $(d)$ and the foreign (host) country illicit sector $(f)$, while middleman traffickers serve as intermediaries delivering trafficked victims from source $d$ to buyers in $d$ and / or $f .{ }^{2}$

Let $V_{i}$ denote the monetary equivalent buyer valuation of the services per victim in $i=d, f$. Buyer willingness to pay depends on two sets of considerations that each individual buyer takes as given: (i) the overall availability of victims in $i$, and (ii) the risk of buyer discovery and prosecution. Each of these considerations depend critically on the likelihood of a crackdown on illicit employment in $d$ and $f$, along with the legal protection offered to transnational victims of trafficking particularly in $f .^{3}$

Specifically, in the domestic country $d$, enforcement of legislation outlawing illicit sector employment, such as legislation banning prostitution, gives rise to a probability $p_{d} \in[0,1]$ of discovery and of buyer penalty $c_{d} \geq 0$. From the perspective of the overall availability of victims in $i$, we specify $V_{i}$ simply as a function of the likelihood that victims remain undiscovered, $V_{d}\left(1-p_{d}\right)$, and assume that $V_{i}(\cdot)$ is positive and strictly decreasing in the perceived availability of victims in $1-p_{d}$, consistent with diminishing marginal utility. Turning to buyer discovery and prosecution, law enforcement gives rise to a probability $p_{d}$ of work stoppage and of buyer penalty. The corresponding

\footnotetext{
${ }^{2}$ Our definition of illicit sector employment, whether domestic or foreign, is simply taken to be any work relationships from which victims trafficking can derive no benefit.

${ }^{3}$ Other country specific reasons that govern the valuation of victims are taken to be embodied in the valuation function $V_{i}$ for each $i$. Our objective here in the model is to specifically assess the role of law enforcement and victim protection. In our empirical analysis, a battery of variables will be used to control other sources of heterogeneity of $V_{i}$ across countries.
} 
maximal willingness to pay per trafficked victim is

$$
\left(1-p_{d}\right) V_{d}\left(1-p_{d}\right)-p_{d} c_{d}
$$

In the foreign country $f$, the likelihood of discovery and of buyer penalty $p_{f}$ is made up of two parts: the frequency of active law enforcement $\rho_{f}$ as well as victim self-reporting $a_{f}$, with $p_{f}=\rho_{f}+a_{f}$. For example, many host countries formally provide protection and other assistance to trafficked victims through the granting of amnesty. We take the victim protection that an amnesty confers - as opposed to a policy of indifference, or one which gives discovered trafficked victims the same legal status as an illegal immigrant for example - to contribute to raising the likelihood of victim discovery from $\rho_{f}$ to $\rho_{f}+a_{f} \in[0,1]$. The corresponding maximal willingness to pay in $f$ is thus:

$$
\left(1-p_{f}\right) V_{f}\left(1-p_{f}\right)-p_{f} c_{f}=\left(1-\rho_{f}-a_{f}\right) V_{f}\left(1-\rho_{f}-a_{f}\right)-\left(\rho_{f}+a_{f}\right) c_{f} .
$$

Denote $\delta_{i} \geq 0$ as the cost required to capture and traffick a victim from $d$ to work in $i$. The net expected value generated per victim trafficked, to be ultimately divided between the buyer and the middleman trafficker, is thus:

$$
E V_{d} \equiv\left(1-p_{d}\right) V_{d}\left(1-p_{d}\right)-p_{d} c_{d}-\delta_{d}
$$

in $d$ and

$$
\begin{aligned}
E V_{f} & \equiv\left(1-\rho_{f}-a_{f}\right) V_{f}\left(1-\rho_{f}-a_{f}\right)-\left(\rho_{f}+a_{f}\right) c_{f}-\delta_{f} \\
& =\left(1-p_{f}\right) V_{f}\left(1-p_{f}\right)-p_{f} c_{f}-\delta_{f}
\end{aligned}
$$

in $f$.

Henceforth, denote $\theta_{j}^{i}$ as the marginal impacts of policy $j$ on the expected value $E V_{i}$ in the illicit sector of country $i$. Of the five policies, $c_{d}, c_{f}, p_{d}, \rho_{f}$ and $a_{f}$, the role of penalty $c_{i}$ is the most straightforward. Since $E V_{i}$ decreases strictly with penalty $c_{i}$, it follows that $\theta_{c}^{i}$ must be strictly negative as long as there is a strictly positive likelihood of discovery $\left(p_{i}>0\right)$ in $i=d, f$ from (1) and (2).

Two opposite forces impact of the role of discovery frequencies $\left(p_{d}\right.$ and $\left.p_{f}=\rho_{f}+a_{f}\right)$ on the net expected value. Working to decrease $E V_{i}$, discovery directly leads to work stoppages and fines. But in opposite direction, discovery also contributes to rising scarcity of workers in $i$, and 
thus the value per worker there $V_{i}(\cdot)$. It follows that if the quantity demand for illicit workers is sufficiently inelastic $\left(\left|\partial \log V_{i} / \partial \log \left(1-p_{i}\right)\right| \gg 1\right)$, the expected value of a victim rises with $p_{d}$ in $d$ and $p_{f}=\rho_{f}+a_{f}$ in $f$, or $\theta_{p}^{d}>0, \theta_{\rho}^{f}>0$, and $\theta_{a}^{f}>0 .^{4}$

\subsection{The Two-Way Bargaining Problem}

Linking victims in $d$ to buyers in $d$ and / or $f$, consider a pool of heterogeneous middleman traffickers in the domestic country, with size normalized to one. ${ }^{5}$ All middleman traffickers enjoy direct cost-free contact with one domestic illicit buyer. Heterogeneity among middleman traffickers can be gauged along two dimensions: (i) their costs of foreign buyer access, and (ii) their reservation income levels as fall back options in case they choose to refrain from trafficking. Specifically, we parameterize the cross-border reach of a trafficker by a search cost $(k \geq 0)$ required to solicit a final buyer in the foreign country. The reservation income of a trafficker will be denoted as $\bar{y} \geq 0$, the forgone income of a trafficker. Assume henceforth that the cumulative distribution function characterizing the pool of heterogeneous middlemen on the two-dimensional $(k, \bar{y})$ plane is given by $G(k, \bar{y})$, with density function $g(k, \bar{y}) \geq 0$ for $k \geq 0$ and $\bar{y} \geq 0$.

The problem of a potential middleman trafficker is two-staged. In the first, he decides whether or not to engage in trafficking. If not, he earns his reservation income $\bar{y}$. Otherwise, a second stage decision needs to be made about the choice between trafficking destinations $d$ and $f$.

Starting from the second stage, we take the clandestine nature of employment in illicit sectors to naturally hinder open competition for trafficked victims. Transaction between a buyer and a trafficker will accordingly be modeled as an outcome of two-way Nash bilateral bargaining. Specifically, the equilibrium incomes of a trafficker delivering a victim to a buyer respectively in $d$ and $f, y_{d}(k)$ and $y_{f}(k)-k$, are the simultaneous solutions to the following Nash bargaining problems:

$$
\begin{aligned}
y_{d}(k) & =\arg \max _{y_{d}}\left[y_{d}-\left(y_{f}(k)-k\right)\right]^{\alpha_{d}}\left[E V_{d}-y_{d}\right]^{1-\alpha_{d}} \\
y_{f}(k)-k & =\max \left\{\arg \max _{y_{f}}\left[y_{f}-y_{d}(k)\right]^{\alpha_{f}}\left[E V_{f}-y_{f}\right]^{1-\alpha_{f}}-k, 0\right\}
\end{aligned}
$$

taking as given host and source policies. (3) - (4) jointly highlight a number of notable features of the two-way bargaining problem. First, $y_{i}$ and $E V_{i}-y_{i}$ together divide the victim's expected

\footnotetext{
${ }^{4}$ Bales (2004) emphasizes the important role of the demand elasticity for trafficked victims, discusses its determinants, and provides arguments suggesting that demand for trafficked victims in illicit sectors is likely inelastic.

${ }^{5}$ The symmetric problem of a middleman trafficker based in the foreign country can be worked out as well. Other than the positioning of the search cost, the analytics are identical to the case considered here.
} 
value $\left(E V_{i}\right)$ completely between the trafficker and the buyer in $i=d, f$. The relative bargaining strength of the middlemen in the exchange is parameterized by $\alpha_{i} \in(0,1)$.

Next, (3) - (4) show that the domestic and foreign illicit markets are inextricably linked in (3) the threat point of a trafficker operating domestically is the expected income that the same trafficker can anticipate in the foreign country $y_{f}(k)-k$, while in (4) the threat point income of the trafficker in the foreign country is the expected income he can earn domestically $y_{d}(k)$. In equilibrium, both threat points are endogenous, to be determined as the joint solutions to the two-way bargaining problem in (3) - (4). The threat point income of the buyers in $i$ in case an agreement cannot be struck is normalized at zero.

Finally, note furthermore that in (3) and (4), traffickers are free to quit at any point, and as such $y_{f}(k)-k$ never falls below zero.

\section{Gains from Transnational Trafficking}

The solution $y_{f}(k)-k$ to $(3)$ - (4) gives the expected income from transnational trafficking as

$$
y_{f}(k)-k=\max \left\{\beta\left(\alpha_{f} E V_{f}-k\right)+\beta_{f} \alpha_{d} E V_{d}, 0\right\},
$$

where $\beta=1 /\left[1-\left(1-\alpha_{d}\right)\left(1-\alpha_{f}\right)\right]$, and $\beta_{f}=\left(1-\alpha_{f}\right) \beta$. As shown, $y_{f}(k)-k$ depends on the expected value of a victim in both $d$ and $f\left(E V_{d}\right.$ and $\left.E V_{f}\right)$, in addition to the bargaining strength of middlemen in $d$ and $f\left(\alpha_{d}\right.$ and $\left.\alpha_{f}\right)$. From (1) and (2), these expected values $E V_{i}$ are in turn dependent on law enforcement $\left(p_{d}\right.$ and $\left.\rho_{f}\right)$, as well as on the degree victim protection accorded in the form of an amnesty $\left(a_{f}\right)$ in $f$.

Schedule $D_{f}$ in Figure 1 illustrates $y_{f}(k)-k$ as the cross-border reach of traffickers $k$ varies, for bargaining strengths of the trafficker $\alpha_{i}$ anywhere in the interior of the range $(0,1)$. Naturally, $D_{f}$ is downward sloping as a higher search cost $k$ decreases a trafficker's income from transnational trafficking. For trafficker immobility sufficiently acute, or $k$ beyond $\widehat{k} \equiv \alpha_{f} E V_{f}+\left(1-\alpha_{f}\right) \alpha_{d} E V_{d}$, the search cost is too high to justify transnational trafficking, and $y_{f}-k$ is thereafter equal to zero.

\section{Gains from Domestic Trafficking}

Now, the other solution to (3) and (4) gives the expected income from domestic trafficking $y_{d}(k)$ :

$$
y_{d}(k)=\max \left\{\beta \alpha_{d} E V_{d}+\beta_{d}\left(\alpha_{f} E V_{f}-k\right), \alpha_{d} E V_{d}\right\}
$$


where $\beta=1 /\left[1-\left(1-\alpha_{d}\right)\left(1-\alpha_{f}\right)\right]$, and $\beta_{d}=\left(1-\alpha_{d}\right) \beta$. Like $y_{f}(k)-k, y_{d}(k)$ depends on the expected values of a victim both in $d$ and $f$, in addition to the bargaining strengths $\alpha_{d}$ and $\alpha_{f}$ of the middleman trafficker. It follows from (1) and (2) that the extent of law enforcement in the two countries $\left(p_{d}\right.$ and $\left.\rho_{f}\right)$ and the availability of victim protection $\left(a_{f}\right)$ will also enter into the determination of the equilibrium income of a trafficker engaged in domestic trafficking, $y_{d}(k)$.

The $D_{d}$ schedule in Figure 1 illustrates $y_{d}(k)$, evaluated at bargaining strengths of the middleman trafficker $\alpha_{i} \in(0,1)$, and assuming in addition that $E V_{f}>E V_{d}$ for otherwise no trafficker will engage in international trafficking. ${ }^{6}$ As shown, $y_{d}(k)$ decreases with search cost $k$, though at a rate strictly less that the slope of $y_{f}(k)-k$ with respect to $k$. Intuitively, the share of a victims' value $y_{d}(k)$ that a domestic trafficker commands depends in part on $y_{f}(k)-k{ }^{7}$ Since the trafficker's threat point income in $d, y_{f}(k)-k$, declines with the cost he must incur to switch between buyer sources, the same trafficker's command on the value of a victim in $d$ likewise declines with $k$. This continues until transnational trafficking is no longer a feasible option at $k \geq \widehat{k}$. Thereafter, further increases in $k$ has no impact on a domestic trafficker's share of the value of a victim, since his threat point income is zero for $k \geq \widehat{k}$. Now, since traffickers' type fall anywhere on the $(k, \bar{y})$ plane, how many will prefer transnational trafficking, domestic trafficking, or no trafficking in equilibrium?

\subsection{Trafficking Equilibrium with Two-Way Bilateral Bargaining}

A trafficking equilibrium with two-way bilateral bargaining is a combination $\left\{\mu_{f}, \mu_{d}\right\}$ representing the the number of traffickers that engage respectively in transnational and domestic trafficking. ${ }^{8}$ Specifically, a trafficker engages in transnational trafficking if he belongs to area $A$ of Figure 1, where $\left\{\left(k, \bar{y}_{d}\right) \mid y_{f}(k)-k=\max \left\{\bar{y}, y_{f}(k)-k, y_{d}(k)\right\}\right\}$. The cutoff $\tilde{k}=\alpha_{f}\left(E V_{f}-E V_{d}\right)$ gives the search cost of the marginal trafficker who is indifferent between transnational and domestic trafficking, or $y_{f}(\tilde{k})-\tilde{k}=y_{d}(\tilde{k})$. Now, area B in Figure 1 illustrates the set of traffickers that engage in domestic trafficking $\left\{\left(k, \bar{y}_{d}\right) \mid y_{d}(k)=\max \left\{\bar{y}, y_{f}(k)-k, y_{d}(k)\right\}\right\}$. It follows that

$$
\mu_{f}=\int_{0}^{\tilde{k}} \int_{0}^{y_{f}(k)-k} g(k, \bar{y}) d \bar{y} d k
$$

\footnotetext{
${ }^{6}$ The opposite case with $E V_{d}>E V_{f}$ can be plotted in symmetric fashion in a figure like Figure 1 . It can be easily confirmed that if $E V_{d}>E V_{f}$, the $D_{f}$ schedule lies uniformly below the $D_{d}$ schedule, and as such no traffickers will engage in international trafficking.

${ }^{7}$ Indeed, $y_{d}(k)$ is as may be expected a weighted average of $E V_{d}$ and $y_{f}(k)-k$, or $y_{d}(k)=\alpha_{d} E V_{d}+\left(1-\alpha_{d}\right)\left(y_{f}(k)-k\right)$ from (3).

${ }^{8}$ The number of middlemen that do not engage in trafficking is thus $1-\mu_{d}-\mu_{f}$.
} 


$$
\mu_{d}=\int_{\tilde{k}}^{\widehat{k}} \int_{0}^{y_{d}(k)} g(k, \bar{y}) d \bar{y} d k+\int_{\widehat{k}}^{\infty} \int_{0}^{\alpha_{d} E V_{d}} g(k, \bar{y}) d \bar{y} d k
$$

For potential traffickers with $(k, \bar{y})$ neither in $A$, or $B$, the fall back option of $\bar{y}$ is preferred. These individuals do not engage in either domestic or transnational trafficking.

We can now consider each of the policies, $a_{f}, \rho_{f}$, and $p_{d}$ in turn, and their effects on transnational trafficking. Supposing for now that buyers demand is sufficiently inelastic, and thus $\theta_{a}^{f}>0, \theta_{\rho}^{f}>0$. In terms of foreign payoffs, a higher likelihood of discovery in the foreign country (due either to victim protection $a_{f}$, or an increase in law enforcement $\rho_{f}$ ) raises a victims value $E V_{f}$ in $f$, raises the trafficker's share $y_{f}(k)-k$ from (6), and accordingly shifts the $D_{f}$ schedule upwards. In terms of domestic payoffs, a higher $y_{f}(k)-k$ raises the threat point income of a domestic trafficker, and shifts $D_{d}$ upwards as well since $y_{d}(k)$ increases with $E V_{f}$ from (7). The combined impacts on transnational trafficking are two-fold. First, stronger foreign demand induced by stricter enforcement abroad raises the likelihood of transnational trafficking by raising the cutoff reservation income $y_{f}(k)-k$ among traffickers with an already low search $\operatorname{cost}(<\tilde{k})$. This encourages transnational trafficking among those who previously prefer the fall back option $\bar{y}$. Second, the same increase in foreign demand also raises the cutoff search cost, $\tilde{k}=\alpha_{f}\left(E V_{f}-E V_{d}\right)$ with $\alpha_{i}>0$. This encourages transnational trafficking among those who previously prefer domestic trafficking. Taken together, foreign legislation that raises the demand for trafficked victims unambiguously increase the likelihood of transnational trafficking, $\mu_{f}$.

Consider instead an increase in law enforcement in the domestic country $p_{d}$. Assuming once again that demand is sufficiently inelastic $\left(\theta_{p}^{d}>0\right)$, stricter domestic enforcement raises a victim's domestic value $E V_{d}$, raises the trafficker's share $y_{d}(k)$, and accordingly shifts the $D_{d}$ upwards. This discourages domestic trafficking among some who would otherwise prefer transnational trafficking as the cut off search cost $\tilde{k}=\alpha_{f}\left(E V_{f}-E V_{d}\right)$ moves to the left with domestic law enforcement. Due to by now familiar reasoning, stricter domestic enforcement also raises the trafficker's share of $E V_{f}$ in the foreign country as their threat point income $y_{d}(k)$ is now higher. This encourages transnational trafficking among those with $k \leq \widehat{k}$ who would otherwise prefer the fall back option. These two effects run in opposite directions, and the net effect depends on whether there is sufficient probability mass among traffickers with low search cost for the threat point income effect to 
dominate, for example. To gauge the size of these two effects, denote:

$$
\mu_{f}^{k}=\int_{0}^{y_{f}(\tilde{k})-\tilde{k}} g(\tilde{k}, \bar{y}) d \bar{y}
$$

as the probability mass of traffickers with the cutoff search cost $\tilde{k}$. These are the first traffickers to switch away from transnational trafficking when the value of domestic trafficking rises. Meanwhile, denote:

$$
\mu_{f}^{y}=\int_{0}^{\tilde{k}} g\left(k, y_{f}(k)-k\right) d k
$$

as the probability mass among transnational traffickers with the threshold reservation income $y_{f}(k)-k$, summing across all those with search cost less than the cutoff. These are traffickers with sufficiently low search cost $k$ but relatively high reservation income, and as such the first to engage in foreign trafficking when a hike in the value of domestic trafficking raises the threat point income of foreign traffickers. The relative size of these two groups of traffickers determine the impact of domestic legislation on transnational trafficking. In what follows, we say that on net, a representative trafficker has considerable ease of mobility between $d$ and $f$ if the ratio $\mu_{f}^{y} / \mu_{f}^{k}$ is sufficiently large. Specifically, ${ }^{9}$

Proposition 1 For all $\alpha_{i} \in(0,1)$, transnational trafficking $\mu_{f}$ rises with amnesty $a_{f}$ and law enforcement $\rho_{f}$ if and only if foreign buyer demand is sufficiently inelastic $\left(\theta_{a}^{f}>0, \theta_{\rho}^{f}>0\right)$.

Transnational trafficking $\mu_{f}$ rises with domestic law enforcement $p_{d}$ as well if and only if buyer demand is sufficiently inelastic $\theta_{p}^{d}>0$, and when traffickers enjoy considerable ease of mobility between $d$ and $f$ :

$$
\frac{\mu_{f}^{y}}{\mu_{f}^{k}}>\frac{\alpha_{f}\left(1-\left(1-\alpha_{d}\right)\left(1-\alpha_{f}\right)\right)}{\alpha_{d}\left(1-\alpha_{f}\right)} \equiv \bar{\alpha} .
$$

Sufficiently inelastic demand, and trafficker mobility facilitated by extensive cross-border buyer connection are thus two key conditions for foreign and domestic law enforcement policies to mutually reinforce one another in expanding the scale of transnational trafficking.

Proposition 1 offers sharp empirical implications, summarized in Table 1A for the case of sufficiently inelastic demand, and in Table 1B for all other demand elasticities. First, consistent with

\footnotetext{
${ }^{9}$ To see the second part of the proposition, differentiate (8) with respect to $p_{d}$ to obtain

$$
\frac{\partial \mu_{f}}{\partial p_{d}}=\left(-\alpha_{f} \mu_{f}^{k}+\frac{\alpha_{d}\left(1-\alpha_{f}\right)}{1-\left(1-\alpha_{f}\right)\left(1-\alpha_{d}\right)} \mu_{f}^{y}\right) \theta_{p}^{d}
$$
}

and the second part of the proposition straightforwardly follows. 
Becker, Grossman and Murphy (2006), Tables 1A and B together demonstrate that the elasticity of demand is paramount. An increase in the incidence of transnational trafficking subsequent to improvements in the frequency of discovery $\rho_{f}+a_{f}$ in $f$ is consistent only with sufficiently inelastic demand, while a reduction in the incidence of transnational trafficking is consistent with all other

demand elasticities. This is true regardless of the cross border reach of traffickers $\left(\frac{\mu_{f}^{y}}{\mu_{f}^{k}}>\bar{\alpha}\right.$, or $\left.\frac{\mu_{f}^{y}}{\mu_{f}^{k}}<\bar{\alpha}\right)$.

Second, whether domestic and foreign law enforcement are found to be mutually reinforcing or run opposite to one another can shed light on the cross-border reach of middlemen traffickers. In particular, law enforcement against illicit sector activities in host $\left(\rho_{f}\right)$ and source $\left(p_{d}\right)$ countries that mutually reinforce one another in encouraging transnational trafficking is consistent only with traffickers that enjoy considerable ease of mobility between host and source countries. This is shown in Table $1 \mathrm{~A}$ where both $p_{d}$ and $\rho_{f}+a_{f}$ are both shown to have negative impacts on trafficking flows, and in Table 1B where both $\rho_{f}$ and $p_{d}$ are shown to have positive impacts on trafficking flows. In all other cases, the effects of $\rho_{f}+a_{f}$ and $p_{d}$ on transnational trafficking bear opposite signs.

\subsection{Extensions of the Basic Model}

Before we proceed to a discussion of the empirical implications of the model, consider two extensions. Respectively, these extensions relax our assumptions on (i) the relative bargaining strength of the trafficker, and (ii) buyer consequences of whether discovery is accomplished by direct law enforcement, or victim self-reports.

\section{Full trafficker bargaining power}

Let us depart from the two-way bargaining problem discussed so far, and consider instead two alternative scenarios. In the first, the middleman trafficker exercises fully his monopoly power and makes a take-it-or-leave-it offer to the buyer equaling the expected value of the victim respectively in the two countries. In the second scenario, the trafficker operates in a competitive environment, in which the price of a victim's services is valued at its expected marginal value product. These are in fact special cases of (5) and (6), upon attributing full bargaining power $\alpha_{d}=\alpha_{f}=1$ to the middleman trafficker. Thus, the trafficker receives as payment the full measure of buyer valuation for a trafficked in country $i$, amounting to $\left(1-p_{d}\right) V_{d}\left(1-p_{d}\right)-p_{d} c_{d}$ in $d$, and $\left(1-\rho_{f}-a_{f}\right) V_{f}(1-$ 
$\left.\rho_{f}-a_{f}\right)-\left(\rho_{f}+a_{f}\right) c_{f}$ in $f$.

Accounting for the cost of trafficking $\delta_{i}$ and the mobility cost $k$ in case of transnational trafficking, these alternative scenarios give rise to trafficker incomes equaling

$$
y_{f}(k)-k=\max \left\{E V_{f}-k, 0\right\} \text { and } y_{d}(k)=E V_{d} \text {. }
$$

respectively in $f$ and $d$. The rest of the analysis thus follows seamlessly, and the corresponding policy comparative statics are shown in Tables $2 \mathrm{~A}$ - B.

Clearly, with full bargaining strength $\alpha_{i}=1$, there is no room left for the threat point income of the trafficker to further contribute to trafficker income in either $d$ or $f$. This simple observation has powerful policy implications. As shown in (9), full trafficker bargaining power severs the link between the traffickers income in $f$, and enforcement policies in $d, p_{d}$. This is shown in Figure 2 , where $y_{d}(k)$ is now a straight line, and independent of the search cost $k$.

Full trafficker bargaining power furthermore severs the critical link between the transnational trafficking response to source country policies and the cross-border mobility of traffickers discussed earlier in Tables 1A and 1B. Instead as shown in Tables 2A and B, the comparative statics of transnational trafficking depends only on the elasticity of buyers demand. Intuitively, when changes in source country policies can no longer impact the income of foreign traffickers, the ability to switch from one buyer to the next is likewise irrelevant in the determination of a trafficker's income in $f$.

Consequently, with full trafficker market power $\left(\alpha_{i}=1\right)$, domestic and foreign country law enforcement activities will never produce mutually reinforcing changes on transnational trafficking flows. Quite the contrary, with sufficiently inelastic buyer demand, for example, foreign enforcement raises a trafficker's income abroad, while domestic enforcement raises a trafficker's income domestically, implying that the combined impact of simultaneously strengthening enforcement in the two countries will have an ambiguous impact on transnational trafficking. For all other demand elasticities, the impact of enforcement policies are simply reversed, and the implied combined impact of simultaneously strengthening enforcement in the two countries on transnational trafficking continues to be ambiguous.

\section{Policy-Specific Buyer Penalties}

We now depart now from the earlier assumption that any type of victim discovery (whether selfreported, or driven by law enforcement) leads directly to successful buyer prosecution. Instead, 
with primary purpose focusing mainly on victim protection, it may be the case that self-reporting of victims facilitated through amnesty is less likely to secure buyer prosecution, or the imposition of fines. Consider therefore as a variant of (2), the case where the expected surplus per trafficked victim in $f$ is

$$
E V_{f}=\left(1-\rho_{f}-a_{f}\right) V_{f}\left(1-\rho_{f}-a_{f}\right)-\rho_{f} c_{f}-\delta_{f}
$$

where the imposition of fines on buyers only apply when discovery is made via direct law enforcement, and not via self-reporting facilitated by amnesty.

Consistent with our conclusions so far, the foreign expected value of a trafficked victim will rise with $\rho_{f}$ if the quantity demand for illicit workers is sufficiently inelastic $\left(\mid \partial \log \left(V_{f}\right) / \partial \log (1-\right.$

$\left.\left.p_{f}\right) \mid \gg 1\right), \theta_{\rho}^{f}>0$. But with amnesty, since an increase in $a_{f}$ no longer imposes the added cost of buyer penalty, it can be readily verified amnesty raises the value $E V_{f}\left(\theta_{a}^{f}>0\right)$ if and only if quantity demand is inelastic $\left(\left|\partial \log \left(V_{f}\right) / \partial \log \left(1-p_{f}\right)\right|>1\right)$.

The corresponding comparative statics responses of transnational trafficking to the three policies $a_{f}, \rho_{f}$, and $p_{d}$ are summarized in Tables $3 \mathrm{~A}$ - D. Here we accommodate for all sixteen cases, allowing for (i) buyers demand that may be elastic, sufficiently inelastic, or somewhere in between, (ii) trafficker bargaining strengths ranging from full to partial, (iii) relatively mobile, and immobile traffickers across the two countries, and (iv) the possibility of policy-specific buyer penalty.

As may be expected, introducing this complication will give rise to divergent transnational trafficking responses to amnesty $a_{f}$ and foreign law enforcement $\rho_{f}$ particularly in the presence of intermediate demand elasticities. Specifically, with elastic or sufficiently inelastic demand, raising the likelihood of discovery either through amnesty or foreign law enforcement will respectively decrease or increase the value of a trafficked victim in the foreign country. With intermediate demand elasticity, however, an amnesty raises the value of a trafficked victim as they become scarce with discovery, but foreign law enforcement by contrast tends to lower the value of a trafficked victim as the likelihood of a fine increases. Tables 3C and 3D highlight the additional nuances in the comparative statics that this extension brings to the model.

\subsection{Empirical Implications}

Tables 1 - 3 show in full view the difficulties that arise with attempts to coordinate an international response to mitigate against transnational trafficking. Clearly, information about demand 
elasticity, trafficker bargaining power, and trafficker mobility across countries, are all key to the design of such an international response. In what follows, the aim of our empirical investigation is precisely to get a handle on these vital characteristics of the market for trafficking that are by nature difficult to directly estimate or proxy for. Our approach is to associate observed trafficking responses to policies in $d$ and $f$ to the relevant combination of demand elasticity, trafficker bargaining power, and trafficker mobility based on Tables 1 - 3. But before we take our comparative statics predictions to the data, there are two sets of issues to consider.

\section{Identification}

The first issue concerns whether it is possible to identify the precise combination of demand elasticity, trafficker bargaining power, and ease of trafficker mobility across countries based on the comparative statics results alone. From Tables 1 - 3, which include in successive stages, the basic model, the first extension incorporating full trafficker bargaining power, and then the second extension furthermore incorporating policy-specific buyer penalty, there are two consistent messages that run throughout, regardless of whether buyer penalty happens to be policy-specific or not:

1. all three policies mutually reinforce each other in influencing international trafficking flows only if (i) there is significant trafficker mobility across countries, and (ii) middleman trafficker enjoys only partial bargaining power,

2. given (i) and (ii) are met, demand elasticity come into play in determining the direction of the impact of all three policies on transnational trafficking. Specifically, all three policies encourage trafficking if demand is sufficiently inelastic, and discourage trafficking for all other demand elasticities.

It follows, therefore, that regardless of the policy specificity of buyer penalties, there are two possible sets of comparative statics responses (\{Neg., Neg., Neg.\}, \{Pos., Pos., Pos. $\})$ that are each consistent with a unique combination of demand elasticity, trafficker bargaining power, and ease of trafficker mobility. In both cases, traffickers face partial bargaining power, and significant ease of trafficker mobility. With positive trafficking response to $a_{f}, \rho_{f}$ and $p_{d}$, the implication is thus that buyer demand is sufficiently inelastic. With negative trafficking responses to these same policies, all other elasticities with the exception of sufficiently inelastic demand apply. 


\section{Measurement}

The second issue concerns the measurement of trafficked victims. By necessity, observed trafficking flow represent the number of discovered victims either through law enforcement, or self-reporting, rather than the actual magnitude of the number of trafficked victims. In the context of our model, denote observed transnational trafficking as $\mu_{f}^{o b s}$ :

$$
\mu_{f}^{o b s}=\left(a_{f}+\rho_{f}\right) \mu_{f}=\left(a_{f}+\rho_{f}\right) \int_{0}^{\tilde{k}} \int_{0}^{y_{f}(k)-k} g(k, \bar{y}) d \bar{y} d k
$$

where $\mu_{f}$ to recall is the actual number of trafficked victims, and $a_{f}+\rho_{f}$ denote the probability that an individual cross-border trafficked victim will be discovered. Our comparative statics exercises presented in Tables 1 - 3 are concerned with the impact of the three policies on actual trafficking flow $\partial \mu_{f} / \partial p_{i}$ and $\partial \mu_{f} / \partial a_{f}$. Turning instead to observed flows:

$$
\frac{\partial \mu_{f}^{o b s}}{\partial a_{f}}=\mu_{f}+\left(a_{f}+\rho_{f}\right) \frac{\partial \mu_{f}}{\partial a_{f}}, \frac{\partial \mu_{f}^{o b s}}{\partial \rho_{f}}=\mu_{f}+\left(a_{f}+\rho_{f}\right) \frac{\partial \mu_{f}}{\partial \rho_{f}}
$$

for foreign (destination) country initiated policies, and

$$
\frac{\partial \mu_{f}^{o b s}}{\partial p_{d}}=\left(a_{f}+\rho_{f}\right) \frac{\partial \mu_{f}}{\partial p_{d}}
$$

for domestic (source) country initiated policy $p_{d}$.

It follows, then, that comparative statics of observed flows with respect to foreign policies may falsely represent the direction of the comparative statics of actual flows. Intuitively, an increase in the likelihood of discovery can generate an increase in the observed flow of (discovered) trafficked victims, even when the total number of trafficked victims has declined.

The only exception to this complication is if the comparative statics are evaluated at the limit where $\mu_{f} \rightarrow 0$ - the extensive margin - since

$$
\lim _{\mu_{f} \rightarrow 0} \frac{\partial \mu_{f}^{o b s}}{\partial a_{f}}=\left(a_{f}+\rho_{f}\right) \frac{\partial \mu_{f}}{\partial a_{f}}, \lim _{\mu_{f} \rightarrow 0} \frac{\partial \mu_{f}^{o b s}}{\partial \rho_{f}}=\left(a_{f}+\rho_{f}\right) \frac{\partial \mu_{f}}{\partial \rho_{f}}, \quad \lim _{\mu_{f} \rightarrow 0} \frac{\partial \mu_{f}^{o b s}}{\partial p_{d}}=\left(a_{f}+\rho_{f}\right) \frac{\partial \mu_{f}}{\partial p_{d}}
$$

where the direction of the comparative statics response based on observed flows is the same as that of the actual flow. Evaluated at $\mu_{f} \rightarrow 0$, Tables $1-3$ are thus applicable to both the actual flow of trafficked victims, and the observed flow of trafficked victims. In the ensuing empirical analysis, it is indeed this extensive margin that we will focus on. 


\section{Data on Human Trafficking}

A paucity of reliable and comparable data has been a key factor hindering research on the forces that determine international trafficking. Research on the topic has so far been based primarily on information gathered from victims of trafficking. ${ }^{10}$ While yielding valuable insights, these studies have a supply-side orientation that is not amenable to analysis of demand-side factors in host countries of trafficking, whether economic, demographic, legislative, or governance related, let alone the characteristics of the market of trafficking highlighted in Section 2.

For this paper, we compiled a dedicated dataset based on the Trafficking in Persons (TIP) Report (US Department of State 2003), and The Protection Project (TPP) Country Report (2002). In terms of a global picture of the incidence of trafficking, the TIP and the TPP are the two most extensive collections of cross-country trafficking information to the best of our knowledge. The TIP report provides extensive qualitative information on host and source countries of trafficking based on reports published in host countries, and only for those host countries where at least 100 cases of trafficking have been discovered in the past year summing across all source countries identified for each host. The TPP report details trafficking routes as well as laws and legislation surrounding trafficking and prostitution in every country. ${ }^{11}$

We combed through the sizeable and extensive country-by-country descriptive accounts in the TIP and the TPP reports to obtain two sets of information for each country. These are, first, whether a country is a host country of trafficking, a source, both (a trafficking hub), or neither. ${ }^{12}$ Second, for each country we identify its trafficking links. For reasons discussed in detail

\footnotetext{
${ }^{10}$ For example, the International Organization of Migration (IOM) has collected data since 1999 from persons assisted under the IOM's counter-trafficking programs. These data from the Counter-Trafficking Module Database (CTM) of the IOM primarily cover trafficking originating from the Balkans (Salt 2005). More recently, a unique data set has been collected by the ILO's Special Action Programme to Combat Forced Labour (SAP-FL). Based on questionnaires from 160 returned migrants in four origin countries (Albania, Romania, Moldova and Ukraine), interviews with informants, focus group discussions and research in seven destination countries (France, Germany, Hungary, Japan, Russia, Turkey and United Kingdom), the SAP-FL database contains 298 entries of forced labor of which 186 are trafficked victims (see Andrees and van der Linden, 2005). Most recently, a study by Mahmoud and Trebesch (2010) analyzes IOM data from 5513 households in Belarus, Bulgaria, Moldova, Romania and Ukraine and shows that migrant families in migration areas and with larger migrant networks are much more likely to be a victim of trafficking.

${ }^{11}$ Copies of the annual U.S. Department of State, Trafficking in Persons Reports can be found at http://www. state.gov/g/tip/rls/tiprpt/. The specific report that we use to construct our data base covers the period April 2002 to March 2003. The Protection Project Report is published by The Johns Hopkins University School of Advanced International Studies and the 2002 report provides information on legislation pertaining to trafficking and prostitution for the year 2002.

${ }^{12}$ We use the year 2002 as a cutoff, for our data on legislation on trafficking and prostitution from the Protection Project Report pertains to that year. Furthermore, since 2003, a wave of national level legislative reforms to
} 
in Section 2, we focus on the extensive margin of trafficking. We do so by constructing a binary

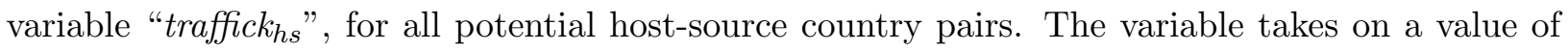
"1" if trafficking from country $s$ to country $h$ has been reported, and " 0 " otherwise. The data in these reports is certainly not comprehensive and clearly unreported cases of trafficking are not accounted for. Nevertheless, it does contain information to support an analysis of broad patterns of trafficking and represents a first attempt at systematically using available information to analyse the interaction between host and source country legislation and incentives of traffickers.

Table 4 lists the 187 countries included in our data and their location in the four-part taxonomy: of the 187 countries in our dataset, 42 countries are identified as source, 45 as hosts, 66 as hubs (or transit countries that act as both source and host) while 44 countries have no reported incidence of trafficking. To shed further light on the characteristics of the countries falling in each category, Table 5 provides category specific information on a few key characteristics. All economic and demographic variables are taken from World Bank (2004) for the year 2000. All legislative and law enforcement related variables are taken from the TPP report. Furthermore, variables capturing political stability, voice and accountability, and rule of law are taken from Kaufmann, Kraay, and Zoido-Lobaton (1999a, 1999b). ${ }^{13}$

\section{Empirical Methodology}

\subsection{Specification}

Our objective in what follows is to identify the push and pull factors which drive transnational trafficking while paying close attention to the effect of two key policy-relevant variables - host country victim protection through amnesty and host and source country legislation against prostitution, a

crackdown on international trafficking has reportedly taken place in response to the UN Protocol to Prevent, Suppress and Punish Trafficking in Persons (UNODC 2009). According to UNODC (2009),

"most legislative frameworks on trafficking in persons have been developed only within the last few years... The UN Protocol entered into force in December 2003. The data shows that the majority of countries did not have any sort of trafficking in persons legislation prior to that year and that most of the current laws criminalizing human trafficking were established after 2003. (p. 22)"

While these developments since 2003 raise intriguing empirical questions, we do not have access to information on the legislative reforms carried out at the individual country level since 2003.

${ }^{13}$ The "rule of law" indicator is a composite index of voice and accountability; political and stability; government effectiveness; regulatory framework; rule of law and control of corruption. The indicator ranges from -3 (worst) to +3 (best). 
sector which constitutes a lion's share of employment for trafficked victims. ${ }^{14}$

To identify the drivers of cross-border trafficking we propose to estimate a modified gravity model. Such models have been widely used to examine trade flows and international migration. In its simplest form, in the migration context, a gravity model specifies international migration flows between an origin and a destination country as a function of income and population in both locations and some measure of the physical distance between countries. ${ }^{15}$ Both origin and destination country characteristics are included to control for the push and pull factors that drive the migration decision.

Drawing on this established literature, we specify and estimate an augmented gravity model. The outcome variable in our trafficking flow model is a measure of whether there is any reported incidence of human trafficking from country $s$ (source) to $h$ (host). Following the standard approach we specify trafficking as a function of per capita GDP (PCGDP) in both the host and the source country. To capture the cost of trafficking, we include a distance variable, a measure of whether countries share a common border, and whether they are in a common region of the world.

In addition to the inclusion of distance, common region and common border effects we include other region specific measures which may have a bearing on trafficking flows. These include for both host and source countries a variable indicating whether the country is a transition economy (from socialist towards market-based economy), whether the country is land-locked and a set of regional fixed effects. Following some of the migration literature (Borjas 1987, Karemara et al. 2000), we furthermore include a set of variables that reflect host and country political conditions. These are, variables which capture rule of law, political stability and voice and accountability in both host and source countries.

Finally, and most importantly, we include whether host and source countries have laws banning prostitution, and whether they have laws which allow for the granting of amnesty to trafficked victims. Whether a country grants amnesty indicates that a country does not treat victims of trafficking in violation of immigration law and subject to deportation, but offers them temporary or permanent residency status. The presence of host (source) country laws banning prostitution

\footnotetext{
${ }^{14} \mathrm{~A}$ recent study conducted by the United Nations Office of Drugs and Crime (UNODC 2009, p. 51) shows that based on information provided by 52 countries, an overwhelming majority (79\%) of the reported incidences of human trafficking involve sexual exploitation.

${ }^{15}$ Papers which employ the gravity model in the immigration context include Sjaastad (1962), Greenwood (1975), Borjas (1987, 1989), and Karemera et al (2000).
} 
is the empirical counterpart for $\rho_{f}\left(p_{d}\right)$, and legal provisions allowing for amnesty is the empirical counterpart of $a_{f}$. We expect that countries which have laws banning prostitution are more likely to enforce laws related to trafficking (at least of women). While it is quite likely that there is a gap between legislation and enforcement in the absence of actual information on law enforcement activities, the use of laws banning prostitution as a proxy for law enforcement related to prostitution, given that it is a sector that account for the bulk of trafficked victims' employment, does not seem unreasonable.

The complete augmented gravity specification may be written as:

$$
\begin{aligned}
\text { Traffick }_{h s}= & \text { PCGDP }_{h(s)}+\text { Distance }_{h s}+\text { Common Region }+ \text { Common Border } \\
& + \text { Region }_{h(s)}+\text { Political Conditions }_{h(s)} \\
& + \text { Grants Legal Amnesty }_{h}+\text { Bans Prostitution }_{h(s)}+\epsilon_{h s} .
\end{aligned}
$$

By way of interpretation, our earlier discussion of Tables 1 - 3 will be used to serve as a guide on the lessons that will be drawn from the observed association between the three policies and Traffick ${ }_{h s}$. Thus, what combination of buyer demand elasticity, trafficker bargaining strength, and trafficker ease of mobility is consistent with the observed empirical association between "Grant

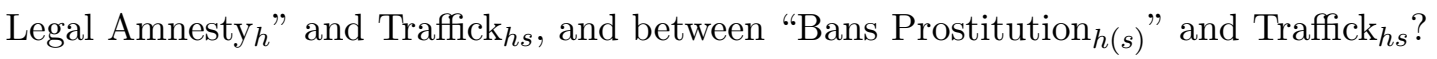

\subsection{Econometric Concerns and Estimation}

Since Traffick $h s$ is a binary variable, assuming that $\epsilon_{h s}$ is normally distributed we begin by estimating several single-equation probit specifications of (11). Given that the main aim of the empirical work is to characterize the market for trafficking by examining the effects of amnesty in a host country and the effect of host and source country prostitution laws (as proxies for law enforcements with regard to trafficking), a relevant econometric concern is whether these three policy related measures and trafficking flows are simultaneously determined. While laws pertaining to prostitution are less likely to be directly linked to trafficking flows, our main concern is about the amnesty variable as it is probably the variable which is most susceptible to a two-way relationship. That is, a country may be more likely to grant amnesty if it experiences a large inflow of trafficking rather than trafficking flows being driven by the provision of amnesty.

An additional but related concern is that since we are using a single cross-section of data and cannot control for country specific unobserved heterogeneity which may influence trafficking flows 
and laws we may obtain biased estimates of the effect of amnesty provision and prostitution related laws on trafficking. For example, unobserved country specific characteristics and values such as tolerance and openness may influence trafficking flows and may also exert an effect on whether a country provides amnesty. Also, the composition of the pattern of exploitation (e.g. forced labor, sexual exploitation) inflicted on trafficked victims may also differ, and as such the relevance of law enforcement on specific illicit sectors of employment (e.g. prostitution) can differ across countries.

We adopt a range of estimation approaches in view of these econometric concerns.

\section{Unobserved Country Values}

An obvious approach to account for unobserved heterogeneity would be to use panel data and allow for country fixed effects. However, such data are not readily available and even if they were, considering that amnesty and prostitution related variables are unlikely to display much variation over time, access to panel data is unlikely to aid identification of the effect of such laws on trafficking. As an alternative, in addition to the inclusion of the country specific socio-political conditions in (11), to account for typically unobserved country values which may influence trafficking flows and the policy-relevant variables of concern we estimate specifications which control for "distaste for foreign neighbors" and a country's views on prostitution. ${ }^{16}$ These data are obtained from the World Values Survey, a source which claims to provide a country-level representative assessment of values and outlook of the residents in various countries (European Values Study Group and World Values Survey Association 2006).

\section{Diverse Patterns of Exploitation}

The next issue concerns the potentially diverse nature of trafficking subsumed under the binary variable "Traffick $h s "$. While transport of women and children for the purpose of sexual exploitation is the predominant reason for trafficking (UNODC 2009), other forms of trafficking, such as forced labor and other forms of exploitation, are also known to exist. Arguably, as long as sexual exploitation is among one of the reasons for trafficking, we would expect laws banning prostitution

\footnotetext{
${ }^{16}$ The question on tolerance of foreign neighbors is: "On this list are various groups of people. Could you please sort out any that you would not like to have as neighbors?" A positive response is recorded as the number one, while a no response is recorded as a zero. The question for the justifiability of prostitution is: Please tell me for each of the following statements whether you think it can always be justified, never be justified, or something in between. A ten point scale is given with 1 equal to never justifiable and 10 equal to always justifiable.
} 
to play a role, for example. Nonetheless, we make use of information just recently made available (UNODC 2009) on regional variations in the patterns of exploitation. Specifically, among Western and Central African countries, forced labor is reportedly a major form of trafficking, though trafficking for sexual exploitation is also observed. Among East African countries, information about the pattern of exploitation is scarce and largely unknown. In all other regions, sexual exploitation is reportedly the predominant form of trafficking. To see the potential impact that these differences in patterns of exploitation on our estimates, we sequentially exclude countries with unknown patterns of exploitation, and / or known patterns of exploitation that are largely not related to sexual exploitation.

\section{Endogeneity and Credibility of Instruments}

Next, to allow for the possible endogeneity between trafficking flows and amnesty we adopt an instrumental variable (IV) approach and provide several IV estimates of (11). We endogenize amnesty and treat it as a function of explanatory variables that are listed in (11) and a set of variables that are assumed to determine amnesty but are assumed not to have a direct bearing on trafficking (excluded from the trafficking equation). Following Vella (1993) we obtain generalized residuals from a first-stage probit regression of amnesty which are subsequently, inserted in (11). This augmented probit equation provides consistent estimates and a test of the null hypothesis that the coefficients on the generalized residuals are zero is a (Hausman) specification test for the exogeneity of amnesty.

While the estimation methodology is straightforward a key concern while implementing IV is the availability of credible instruments. To estimate the impact of amnesty on trafficking we need variables that are correlated with the probability that a country grants amnesty but which, conditional on other controls, do not exert an effect on trafficking flows, other than through their effect on amnesty provisions. There are several sets of potentially relevant instruments.

In recent years, a large body of literature has shown that a country's legal origins have a direct bearing on its legal framework in several spheres and through these laws on economic and social outcomes. ${ }^{17}$ More specifically, LaPorta et al. $(1997,1998)$ use a country's legal origins as

\footnotetext{
${ }^{17}$ For more details on the link between legal origins and laws in different spheres including labor laws, company and security law see LaPorta et al. (2008). For the link between legal origins and constitutional commitments to education, health, housing and worker's rights see Ben-Bassat and Dahan (2008).
} 
an instrument for its legal rules to identify the effect of laws on outcomes of interest. Taking a cue from this literature we argue that laws regarding amnesty are likely to be influenced by a country's legal origins but are unlikely to exert a direct effect on trafficking patterns. While laws do evolve, the legal origin theory argues that the origins of a legal system continue to exert a substantial influence on its current legal system and that each legal system is marked by an "ideology, that is, a religious or political conception of how economic or social life should be organized" (Zweigert and Kotz, 1998, p.72). Following Reynolds and Flores (1989) each country in our data set is classified into one of five groups (Socialist, English common law, and civil law which is further divided into French, Scandinavian and German origin) and subsequently the set of variables indicating a country's legal origins are used to instrument amnesty.

While it is quite likely that a country's legal origins are correlated with the probability that it grants amnesty, the exclusion restriction that legal origins do not have a direct bearing on trafficking flows may be challenged. If legal origins are viewed as a general indicator of how economic and social life should be organized then these instruments may capture country-level unobserved attitudes such as openness or tolerance and may indeed have a direct bearing on trafficking flows. We adopt two approaches to examine the extent to which our estimates may be driven by such omitted variables. First, we estimate several IV models including specifications which control for a number of variables which are likely to be correlated with trafficking flows and legal origin. These include measures of the rule of law, voice and accountability, and political stability. Of course it is not possible for us to control for all variables that might be correlated with legal origins and trafficking flows, hence in addition to these sensitivity checks we examine the validity of the instruments by using an overidentification test. To implement the test we use the mortality rate of European settlers in colonies between the seventeenth and the nineteenth century as an additional instrument for amnesty. This variable has been used most famously by Acemoglu et al. $(2000,2001)$ to instrument institutions and is based on the argument that colonies with high rates of settler mortality were less attractive for European settlers and hence less likely to have developed institutions conducive to economic development. Drawing a parallel we argue that countries with high settler morality rates are less like to have developed the legal infrastructure and institutions that would allow for the granting of amnesty to trafficked people. For instance, in a country with high settler mortality there would be little need for strong immigration and amnesty 
legislation. $^{18}$

\section{Regression Results}

\subsection{Single Equation Estimates}

Single equation estimates of several variants of (11) are provided in Table 6 . The first specification includes only the key variables of interest (amnesty and prostitution laws) while subsequent specification expands the model to include additional regressors. Specification 2 includes GDP and distance related measures, while specification 3 controls additionally for landlocked and transitional economies. Specification 4 includes measures to control for regional fixed effects, while specifications 5 and 6 include controls for country specific social and political conditions, respectively without and with regional fixed effects.

Focusing on the key variables of interest, as shown in the table, regardless of the specification, the estimates indicate that the granting of amnesty by a host country is statistically significant and positively associated with trafficking flows. The marginal effect ranges from 0.8 (column 4) to 5.7 (column 1) percentage points and while the inclusion of various regressors reduces the magnitude of the coefficient, it remains remarkably stable across specifications. Except for specification 1 which includes only the key policy-relevant variables, the magnitude of the coefficient lies between between 0.8 and 1.5 percentage points. Across the board we see that there is a positive link between host country amnesty provision and trafficking flows suggesting is not associated with a decrease in the probability of discovery (cost of trafficked individuals) does not hinder trafficking flows.

In terms of laws prohibiting prostitution, the estimates are also stable across specifications and display a positive link between host country prostitution laws and the probability of trafficking. However, the estimates are small in magnitude and are not statistically significant. Similarly, the coefficients on source country prostitution laws are also positive, small and not statistically significant at conventional levels. Notwithstanding their insignificance both sets of laws have a positive sign indicating that increases in law enforcement related to illicit sector activities in both host and source countries mutually reinforce one another and are likely to increase rather than decrease trafficking flows.

\footnotetext{
${ }^{18}$ The European settler mortality rate defined in terms of deaths per thousand is available for 73 countries. It is based on the mortality rates of soldiers, bishops and sailors working in various colonies over the 17th and 19th centuries. For more details see Acemoglu et al. (2001). Since the measure of settler mortality is computed in the 19 th century it should have no bearing on current trafficking flows except through the endogenous variable.
} 
In light of the discussion in section 2 and Tables 1-3, the estimates related to amnesty and prostitution laws jointly support the idea that the market for transnational trafficking is characterized by inelastic demand, partial trafficker bargaining power, and that middlemen have access to an internationally diverse buyer base and are able to readily switch between domestic and foreign markets.

Appendix Table 1 displays single regression estimates after controlling for potential unobserved heterogeneity in country values towards foreign neighbors and towards prostitution. To account for the potentially diverse forms of exploitation subsumed under "Traffick $h$ " Appendix Tables 2, 3 and 4 successively exclude East African countries, ${ }^{19}$ Western and Central African countries ${ }^{20}$ and both East, Western and Central African countries. While the number of observations is greatly reduced in some cases, the resulting estimates are evidently quite robust, and uniformly display a positive link between amnesty, source country prostitution laws, and host country prostitution laws on trafficking. With these observations, in what follows we will return to the full sample in order to carry out instrumental variable estimations.

\subsection{Instrumental Variable Estimates}

Tables 7a, 7b and 7c, present IV estimates (6 specifications in each table) based on different sets of instrument. The estimates in Table 7a are based on the use of legal origins as an instrument, Table $7 \mathrm{~b}$ is based on the use of settler mortality as an instrument while Table $7 \mathrm{c}$ uses both. The first stage estimates corresponding to each of the IV estimates is provided in columns 1 to 3 of Appendix Table 5.

Before turning to the second-stage estimates a few comments on the first stage estimates, in particular, the strength of the instruments is in order. Column 1 shows that countries with French or German legal origin as opposed to countries with other legal origins are more likely to provide amnesty. The greater likelihood of amnesty provisions in countries with a civil law tradition is consistent with the findings of Ben-Bassat and Dahan (2008) who find that countries with a civil law tradition tend to have a higher constitutional commitment to social rights as compared to countries with a common law tradition. Jointly and individually, the two legal origin variables are statistically significant and a joint statistical test for excluding the instruments records a p-value of

\footnotetext{
${ }^{19}$ These include Burundi, Djibouti, Eritrea, Ethiopia, Kenya, Mauritius, Rwanda, Tanzania, and Uganda.

${ }^{20}$ These include Benin, Burkina Faso, Chad, Cote d'Ivoire, Gabon, Gambia, Ghana, Liberia, Mali, Mauritania, Niger, Nigeria, Senegal, Sierra Leone, Togo
} 
less than 0.01. Column 2 estimates which are based on settler mortality as an instrument show that countries which recorded higher rates of settler mortality are less likely to grant amnesty. Although, data on this measure is available for a smaller set of countries, the instrument is statistically significant and records a p-value of less than 0.01. In column 3 both instruments are statistically significant although the sign of the legal origin variable flips. Nevertheless, the requirement that the instruments should be (highly) correlated with amnesty holds across all three specifications. ${ }^{21}$

Table 7a provides IV estimates based on legal origins as an instrument. Table 7b is based on settler mortality as an instrument, and Table 7c uses both legal origin and settler mortality as instruments. Results in Table 7a show that the generalized residual is not statistically significant and that there is no need to endogenize amnesty. However, in the first column of Table $7 \mathrm{~b}$ and all except one specification in Table $7 \mathrm{c}$ the term is negative and statistically significant indicating that in the absence of this correction there would be a tendency to underestimate the effect of amnesty on trafficking. Consistent with this, the IV estimates of amnesty in Tables 7b and 7c are positive, statistically significant and larger than their single equation counterparts.

As in the case of the single equation estimates, both host and source country prostitution laws exert a positive and mutually reinforcing effect on international trafficking. The main change here is that these effects are now statistically significant, and uniformly so in specifications 4 and 6 where regional fixed effects are included. This change is not due to an increase in the magnitude of the coefficient which still remains small, but due to the increased precision with which the coefficient is measured.

Overall, qualitatively there is not much difference between the single equation and IV estimates. In both cases and across a variety of specifications there is a positive, large and statistically significant effect of amnesty on trafficking flows. Across our empirical analysis, the effects of both host and source country prostitution laws remain positive and small and the coefficients on these variables are statistically significant when both legal origins and settler mortality are used as instrument, upon controlling for regional fixed effects.

Based on these estimates, our empirical findings is consistent with the co-existence of the

\footnotetext{
${ }^{21}$ Following Stock, Wright and Yogo (2002), the strength of the instruments may be gauged by examining the Fstatistic on the instruments in the first stage. In order to do so we estimated the first stage regression using a linear probability model. In all three cases the first stage F-statistics were substantially higher than the benchmark of 10 for two-stage least squares to be reliable. To examine the validity of the instruments we conducted an overidentification test using linear probability models. The test statistic recorded a p-value of 0.919 indicating that the null hypothesis that the instruments are not correlated with the error term in the equation of interest cannot be rejected.
} 
following sets of characteristics of the market for trafficking:

1. buyer valuation exhibit a sufficiently inelastic demand, suggesting that stricter enforcement will raise the market value of trafficked victims;

2. middleman traffickers do not have full bargaining power, and as such the gains from trafficking depends at least in part on the bargaining position of the trafficker. This implies that law enforcement targeting trafficked victims in the domestic source (foreign host) country can cast a non-trivial impact on the bargaining outcome in foreign host (domestic source) countries, and

3. middleman traffickers exhibit a considerable degree of cross-border mobility. With (1) and (2), the addition of (3) suggests that domestic and foreign law enforcement activities in illicit sectors of employment tend to have a positive, and mutually reinforcing impact on the incidence of transnational trafficking.

\section{Conclusion}

We began this paper with two sets of questions - what is the trafficking impact of a crackdown on illicit activities in the source country if the bargaining position of footloose transnational traffickers hinges on a threat to switch to a domestic buyer source? What about a similar hike in the likelihood of discovery in the foreign country? Our goal is to contribute to the debate on the coordination of international efforts to curb transnational trafficking, by means of laws that directly act on the demand side incentives that encourage individuals to engage in trafficking. Our theoretical model shows within the context of a two-way bilateral bargaining problem that the answers to these questions are nuanced. In particular, crackdowns on illicit employment of trafficked victims in the host and the source countries can be mutually reinforcing, or can counteract one another depending precisely on middlemen bargaining power, whether traffickers enjoy ready access to an internationally diverse buyer base, and the demand elasticity of the demand for trafficked victims.

Based on a novel dataset of international trafficking, we empirically ascertained the drivers of cross-border trafficking, including victim protection programs, and law enforcement against prostitution. Our empirical assessment paid particular attention to the endogeneity of victim protection legislation, and country specific unobserved heterogeneity. We present results from single 
equation estimates, and instrumental variable estimates using legal origin and settler mortality as instruments. In both cases, and across a variety of specifications, our findings show that the impacts of both host and source country legislation prohibiting prostitution on trafficking are positive. These findings are consistent with an inelastic demand for trafficked victims, partial bargaining power of traffickers, and considerable ease of access across domestic and foreign markets.

In terms of the debate concerning whether a heightened likelihood of discovery in illicit service sectors can stem the tide of transnational trafficking, these findings lend support to the view that with inelastic demand, heightened enforcement in the host country can raise the willingness to pay for trafficked victims in the host country, thus encouraging transnational trafficking. Meanwhile, with partial bargaining power, and considerable ease of access between domestic and foreign markets, heightened enforcement in the source country can indeed "play into the hands of criminal networks" (Bureau of the Dutch National Rapporteur on Trafficking 2005), by raising the (threat point) reservation price of trafficked victims, and accordingly the profitability of transnational trafficking.

A number of other important questions remain. A key issue raised in this paper is that domestic and international trafficking activities are simultaneously determined. This suggests not only that domestic legislation can spill over to impact international trafficking, but likewise international enforcement of anti-trafficking initiatives can impact domestic trafficking activities as well. This observation naturally suggest the need to empirically ascertain the link between trafficking related policy measures and illicit domestic employment. In addition, the model that we explored is in fact equally applicable for other forms of illicit international trade such as drugs and antiquities. Empirical work on these alternative areas where middleman traffickers operate can be equally illuminating.

\section{Reference}

Acemoglu, Daron, Simon Johnson and James A. Robinson. 2001. "The Colonial Origins Of Comparative Development: An Empirical Investigation," American Economic Review 91 (5): 1369-1401.

Acemoglu, Daron, Simon Johnson and James A. Robinson. 2000. "The Colonial Origins Of Comparative Development: An Empirical Investigation," NBER Working Paper \#7771. 
Andrees, Beate, and Mariska N. J. van der Linden. 2005. "Designing Trafficking Research from a Labour Market Perspective: The ILO Experience," International Migration 43 (1/2): 55 74 .

Bales, Kevin. 1999. "What Predicts Human Trafficking? Proceedings of the United Nations Conference on Human Trafficking, Verona, October.

Bales, Kevin. 2004. "Understanding the Demand behind Human Trafficking." Mimeo. http: //www. childtrafficking.com/Docs/bales__understanding_the_de.pdf

Basu, Arnab K. and Nancy H. Chau. 2008. "An Exploration of the Worst Forms of Child Labor: Is Redemption a Viable Option?" In The Economics and Ethics of Slave Redemption, K. Anthony Appiah and Martin Bunzel (eds), Princeton University Press, Princeton, New Jersey.

Becker, Gary S., Kevin M. Murphy and Michael Grossman. 2006. "The Market for Illegal Goods: The Case of Drugs." Journal of Political Economy 114 (1): 38 - 60.

Ben-Bassat, Avi and Momi Dahan. 2008. "Social Rights in the Constitution and in Practice," Journal of Comparative Economics 36(1): 103 - 119.

Borjas, George J. 1989. "Economic Theory and International Migration," International Migration Review 23(3) : 457-85.

Borjas, George J. 1987. "Self-selection and the Earnings of Immigrants," American Economic Review 77(4) : 531-53.

Bureau of the Dutch National Rapporteur on Trafficking in Human Beings. 2005. Trafficking in Human Beings. Bureau NRM, The Hague.

Busse, Matthias and Sebastian Braun. 2002. "Trade and Investment Effects of Forced Labour: An Empirical Assessment." Hamburg Institute of International Economics Discussion Paper 200.

Danailova-Trainor, Gergana and Patrick Belser. 2006. "Globalization and the Illicit Market for Human Trafficking: An Empirical Analysis of Demand and Supply." ILO Special Action Programme to combat Forced Labor Working Paper no. 53.

Dessy, Sylvain, Flaubert Mbiekop and Stèphane Pallage. 2004. "The Economics of Child Trafficking." Mimeo.

European and World Value Surveys Four-Wave Integrated Data File, 1981-2004, v.20060423, 2006. 
Aggregate File Producers: Análisis Sociológicos Económicos y Políticos (ASEP) and JD Systems (JDS), Madrid, Spain/Tilburg University, Tilburg, The Netherlands. Data Files Suppliers: Análisis Sociologicos Economicos y Politicos (ASEP) and JD Systems (JDS), Madrid, Spain/Tillburg University, Tillburg, The Netherlands/ Zentralarchiv fur Empirische Sozialforschung (ZA), Cologne, Germany:) Aggregate File Distributors: Análisis Sociológicos Económicos y Políticos (ASEP) and JD Systems (JDS), Madrid, Spain/Tillburg University, Tilburg, The Netherlands/Zentralarchiv fur Empirische Sozialforschung (ZA) Cologne, Germany.

Friebel, Guido and Sergei Guriev. 2006. "Smuggling Humans: A Theory of Debt-Financed Migration", Journal of the European Economic Association 4 (6): 1085-1111.

Greenwood, Michael. 1975. "Research on National Migrational in the United States: A Survey," Journal of Economic Literature 13, 397-433.

ILO. 2009. The Cost of Coercion, Global Report under the follow-up to the ILO Declaration on Fundamental Principles and Rights at Work. International Labour Conference, Geneva.

ILO. 2005. A Global Alliance Against Forced Labour, Global Report under the follow-up to the ILO Declaration on Fundamental Principles and Rights at Work. International Labour Conference, Geneva.

Karemera, David, Victor Iwuagwu Oguledo and Bobby Davis. 2000. "A Gravity Model Analysis of International Migration to North America," Applied Economics 32(13): 1745-55.

Kaufmann, Daniel, Aart Kraay and Pablo Zoido-Lobaton 1999a. "Aggregating Governance Indicators". World Bank Policy Research Department Working Paper No. 2195.

Kaufmann, Daniel, Aart Kraay and Pablo Zoido-Lobaton 1999b. "Governance Matters", World Bank Policy Research Department Working Paper No. 2196.

La Porta, Rafael, Florencio Lopez-de-Silanes, Andrei Shleifer and Robert W. Vishny. 1998. "Law and Finance," Journal of Political Economy 106 (6): 1113-1155.

La Porta, Rafael, Florencio Lopez-de-Silanes, Andrei Shleifer and Robert W. Vishny. 1997. "Legal Determinants of External Finance," Journal of Finance 52 (3): 1131-1150.

La Porta, Rafael, Florencio Lopez-de Silanes and Andrei Shleifer. 2008. "The Economic Consequences of Legal Origins," Journal of Economic Literature 46 (2): 285-332.

Mahmoud, Toman Omar, and Christoph Trebesch. 2009. "The Economic Drivers of Human 
Trafficking: Micro-Evidence from Five Eastern European Countries.” Mimeo.

Reynolds, Thomas and Arturo Flores. 1989. Foreign Law: Current Sources of Basic Legislation in Jurisdictions of the World. Littleton, Co.: Rothman and Company.

Rogers, Carol Ann and Kenneth A. Swinnerton. 2008. "A Theory of Exploitative Child Labor." Oxford Economic Papers 60 (1): 20-41.

Salt, John. 2005. Current Trends in International Migration in Europe, Strasbourg: Council of Europe Publishing, September.

Stock, James., Jonathan Wright, and Yogo Motohiro. 2002. ”A survey of weak instruments and weak identification in generalized methods of moments," Journal of Business and Economic Statistics, 20(4) 518-529.

Sjaastad, L. A. 1962. "The Cost and Returns of Human Migration," Journal of Political Economy 70: $80-93$.

Protection Project. 2002. Human Rights Report on Trafficking in Persons, Especially Women and Children. The Johns Hopkins University.

UNICEF 2003. "Trafficking in Human Beings Especially Women and Children in Africa", Innocenti Research Center, Florence, Italy.

UNODC. 2009. Global Report on Trafficking in Persons. United Nations Office of Drugs and Crimes. United Nations Office.

United States Department of State. Various Issues. Trafficking in Persons Report. Office of the Undersecretary for Global Affairs. United States Department of State Publication.

Vella, Frank. 1993. "A Simple Estimator for Simultaneous Models with Censored Endogenous Regressors. International Economic Review 34(2), 441-457.

World Bank. 2004. World Development Indicators. CD-ROM. Washington DC: The World Bank. Zweigert, Konrad and Hein Kotz. 1998. An Introduction to Comparative Law. Third Edition. Oxford and New York: Oxford University Press, Clarendon Press. 


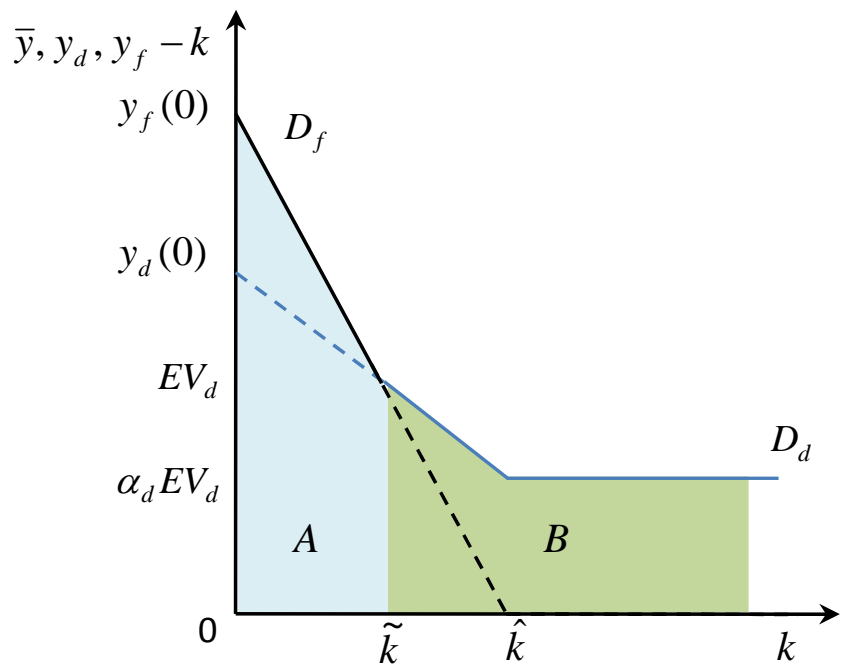

Figure 1.

Trafficker Destination Choice

$\alpha_{i} \in(0,1)$

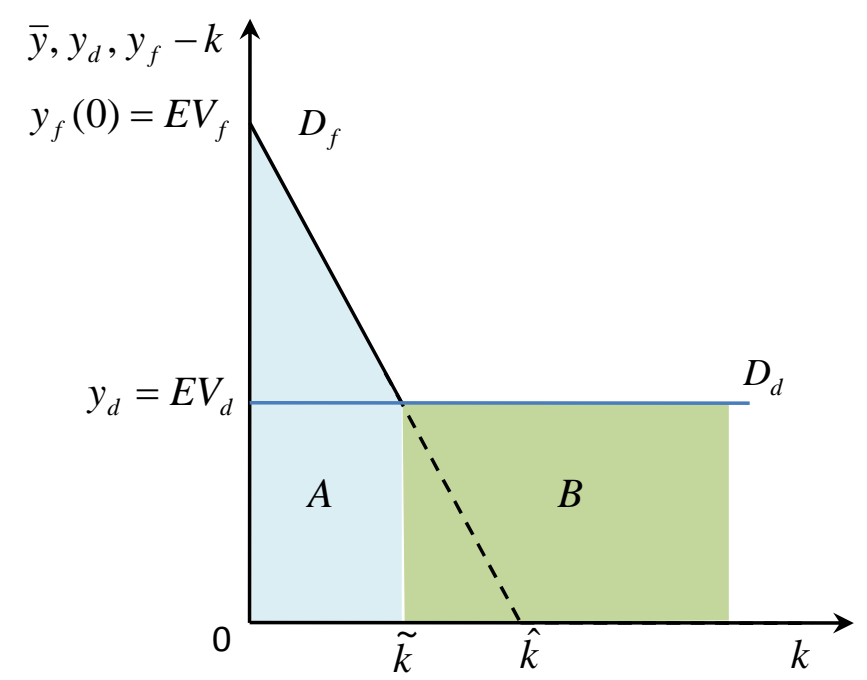

Figure 2.

Trafficker Destination Choice

$\alpha_{i}=1$ 
Table 1A.

Effects of $\boldsymbol{a}_{\boldsymbol{f}}, \boldsymbol{\rho}_{\boldsymbol{f}}$, and $\boldsymbol{p}_{\boldsymbol{d}}$ on Transnational Trafficking $\boldsymbol{\mu}_{\boldsymbol{f}} \quad$-- Sufficiently Inelastic Demand $\left(\theta_{a}^{f}>0, \theta_{\rho}^{f}>0, \theta_{p}^{d}>0\right)$,

buyer penalty applies regardless of the reason for discovery

\begin{tabular}{|c|c|c|}
\hline & $\mu_{f}^{y} / \mu_{f}^{k}<\bar{\alpha}$ & $\mu_{f}^{y} / \mu_{f}^{k}>\bar{\alpha}$ \\
\hline$\alpha_{i} \in(0,1)$ & Pos., Pos., Neg. & Pos., Pos., Pos. \\
\hline
\end{tabular}

Table 1B.

Effects of $\boldsymbol{a}_{\boldsymbol{f}}, \boldsymbol{\rho}_{\boldsymbol{f}}$, and $\boldsymbol{p}_{d}$ on Transnational Trafficking $\boldsymbol{\mu}_{\boldsymbol{f}}$-- All Other Demand Elasticities $\left(\theta_{a}^{f}<0, \theta_{\rho}^{f}<0, \theta_{p}^{d}<0\right)$

buyer penalty applies regardless of the reason for discovery

\begin{tabular}{|c|c|c|}
\hline & $\mu_{f}^{y} / \mu_{f}^{k}<\bar{\alpha}$ & $\mu_{f}^{y} / \mu_{f}^{k}>\bar{\alpha}$ \\
\hline$\alpha_{i} \in(0,1)$ & Neg., Neg., Pos. & Neg., Neg., Neg. \\
\hline
\end{tabular}

Table 2A.

Effects of $a_{f}, \rho_{f}$, and $p_{d}$ on Transnational Trafficking $\mu_{f} \quad$-- Sufficiently Inelastic Demand $\left(\theta_{a}^{f}>0, \theta_{\rho}^{f}>0, \theta_{p}^{d}>0\right)$,

buyer penalty applies regardless of the reason for discovery

\begin{tabular}{|c|c|c|}
\hline & $\mu_{f}^{y} / \mu_{f}^{k}<\bar{\alpha}$ & $\mu_{f}^{y} / \mu_{f}^{k}>\bar{\alpha}$ \\
\hline$\alpha_{i}=1$ & Pos., Pos., Neg. & Pos., Pos., Neg. \\
\hline
\end{tabular}

Table 2B.

Effects of $\boldsymbol{a}_{\boldsymbol{f}}, \boldsymbol{\rho}_{\boldsymbol{f}}$, and $\boldsymbol{p}_{\boldsymbol{d}}$ on Transnational Trafficking $\boldsymbol{\mu}_{\boldsymbol{f}}$-- All Other Demand Elasticities $\left(\boldsymbol{\theta}_{\boldsymbol{a}}^{\boldsymbol{f}}<0, \boldsymbol{\theta}_{\boldsymbol{\rho}}^{\boldsymbol{f}}<0, \boldsymbol{\theta}_{\boldsymbol{p}}^{\boldsymbol{d}}<0\right)$,

buyer penalty applies regardless of the reason for discovery

\begin{tabular}{|c|c|c|}
\hline & $\mu_{f}^{y} / \mu_{f}^{k}<\bar{\alpha}$ & $\mu_{f}^{y} / \mu_{f}^{k}>\bar{\alpha}$ \\
\hline$\alpha_{i}=1$ & Neg., Neg., Pos. & Neg., Neg., Pos. \\
\hline
\end{tabular}


Table 3A.

Effects of $\boldsymbol{a}_{f}, \boldsymbol{p}_{\boldsymbol{f}}$, and $\boldsymbol{p}_{\boldsymbol{d}}$ on Transnational Trafficking $\boldsymbol{\mu}_{f}$-- Sufficiently Inelastic Demand $\left(\boldsymbol{\theta}_{\boldsymbol{a}}^{f}>0, \boldsymbol{\theta}_{\boldsymbol{p}}^{\boldsymbol{i}}>0, i=d, f\right)$,

buyer penalty applies either regardless of the reason for discovery, or only through law enforcement

\begin{tabular}{|c|c|c|}
\hline & $\mu_{f}^{y} / \mu_{f}^{k}<\bar{\alpha}$ & $\mu_{f}^{y} / \mu_{f}^{k}>\bar{\alpha}$ \\
\hline$\alpha_{i}=1$ & Pos., Pos., Neg. & Pos., Pos., Neg. \\
\hline$\alpha_{i} \in(0,1)$ & Pos., Pos., Neg. & Pos., Pos., Pos. \\
\hline
\end{tabular}

Table 3B.

Effects of $a_{f}, \rho_{f}$, and $p_{d}$ on Transnational Trafficking $\mu_{f}$-- Elastic Demand $\left(\theta_{a}^{f}<0, \theta_{\rho}^{f}<0, \theta_{p}^{d}<0\right)$

buyer penalty applies either regardless of the reason for discovery, or only through law enforcement

\begin{tabular}{|c|c|c|}
\hline & $\mu_{f}^{y} / \mu_{f}^{k}<\bar{\alpha}$ & $\mu_{f}^{y} / \mu_{f}^{k}>\bar{\alpha}$ \\
\hline$\alpha_{i}=1$ & Neg., Neg., Pos. & Neg., Neg., Pos. \\
\hline$\alpha_{i} \in(0,1)$ & Neg., Neg., Pos. & Neg., Neg., Neg. \\
\hline
\end{tabular}

Table 3C.

Effects of $\boldsymbol{a}_{f}, \rho_{f}$, and $\boldsymbol{p}_{\boldsymbol{d}}$ on Transnational Trafficking $\boldsymbol{\mu}_{\boldsymbol{f}}$-- Intermediate Demand Elasticity $\left(\theta_{a}^{f}<0, \theta_{\rho}^{f}<0, \theta_{p}^{d}<0\right)$,

buyer penalty applies regardless of the reason for discovery

\begin{tabular}{|c|c|c|}
\hline & $\mu_{f}^{y} / \mu_{f}^{k}<\bar{\alpha}$ & $\mu_{f}^{y} / \mu_{f}^{k}>\bar{\alpha}$ \\
\hline$\alpha_{i}=1$ & Neg., Neg., Pos. & Neg., Neg., Pos. \\
\hline$\alpha_{i} \in(0,1)$ & Neg., Neg., Pos. & Neg., Neg., Neg. \\
\hline
\end{tabular}

Table 3D.

Effects of $\boldsymbol{a}_{\boldsymbol{f}}, \boldsymbol{\rho}_{\boldsymbol{f}}$, and $\boldsymbol{p}_{\boldsymbol{d}}$ on Transnational Trafficking $\boldsymbol{\mu}_{\boldsymbol{f}}$ - Intermediate Demand Elasticity $\left(\theta_{a}^{f}>0, \theta_{\rho}^{f}<0, \theta_{p}^{d}<0\right)$,

buyer penalty applies only through law enforcement

\begin{tabular}{|c|c|c|}
\hline & $\mu_{f}^{y} / \mu_{f}^{k}<\bar{\alpha}$ & $\mu_{f}^{y} / \mu_{f}^{k}>\bar{\alpha}$ \\
\hline$\alpha_{i}=1$ & Pos., Neg., Pos. & Pos., Neg., Pos. \\
\hline$\alpha_{i} \in(0,1)$ & Pos., Neg., Pos. & Pos., Neg., Neg. \\
\hline
\end{tabular}


Table 4. List of Countries and Status of Trafficking

\begin{tabular}{|c|c|c|c|c|}
\hline Non & Host & Hub & & Source \\
\hline Andorra & Antigua & Afghanistan & Poland & Algeria \\
\hline Bahamas & Australia & Albania & Romania & Angola \\
\hline Barbados & Austria & Argentina & Russian Fed. & Armenia \\
\hline Burundi & Belgium & Bahrain & Senegal & Azerbaijan \\
\hline Comoros & Belize & Bangladesh & Slovakia & Belarus \\
\hline Croatia & Bosnia \& Herzegovina & Benin & South Africa & Bhutan \\
\hline Djibouti & Botswana & Brazil & South Korea & Bolivia \\
\hline Egypt & Canada & Brunei & Sri Lanka & Cape Verde \\
\hline Eritrea & Central African Rep. & Bulgaria & Sudan & Colombia \\
\hline Fiji & Chile & Burkina Faso & Taiwan & Cuba \\
\hline Iceland & Cote d'Ivoire & Cambodia & Tanzania & Ecuador \\
\hline Jamaica & Denmark & Cameroon & TFYR Macedonia & Estonia \\
\hline Lesotho & Finland & Chad & Thailand & Ethiopia \\
\hline Liechtenstein & France & China & Togo & Georgia \\
\hline Luxembourg & Gabon & Congo, Dem. Rep. & Turkey & Guyana \\
\hline Maldives & Gambia & Costa Rica & Uganda & Honduras \\
\hline Malta & Germany & Cyprus & Ukraine & Iraq \\
\hline Marshall Islands & Greece & Czech Republic & Uzbekistan & Kenya \\
\hline Micronesia & Hong Kong (SAR) & Dominican Rep. & Venezuela & Latvia \\
\hline Monaco & Israel & El Salvador & Vietnam & Madagascar \\
\hline Namibia & Italy & Equatorial Guinea & Zimbabwe & Malawi \\
\hline Nauru & Japan & Ghana & & Mauritania \\
\hline New Zealand & Kuwait & Guatemala & & Moldova \\
\hline Niue & Lebanon & Haiti & & Morocco \\
\hline Oman & Libya & Hungary & & Mozambique \\
\hline Palau & Macau (SAR) & India & & Nepal \\
\hline Palestine & Mauritius & Indonesia & & Nicaragua \\
\hline Papua New Guinea & Netherlands & Iran & & Sierra Leone \\
\hline Paraguay & Norway & Kazakhstan & & Slovenia \\
\hline Saint Kitts and Nevis & Portugal & Kosovo & & Somalia \\
\hline $\begin{array}{l}\text { Saint Lucia } \\
\text { Saint Vincent and the }\end{array}$ & Qatar & Kyrgyzstan & & Tajikistan \\
\hline Grenadines & Rwanda & Laos & & Zambia \\
\hline Samoa & Saudi Arabia & Liberia & & \\
\hline San Marino & Singapore & Lithuania & & \\
\hline Sao Tome and and Principe & Spain & Malaysia & & \\
\hline Seychelles & Suriname & Mali & & \\
\hline Solomon Islands & Swaziland & Mexico & & \\
\hline Tonga & Sweden & Mongolia & & \\
\hline Trinidad and Tobago & Switzerland & Myanmar & & \\
\hline Tunisia & Syria & Niger & & \\
\hline Turkmenistan & United Arab Emirates & Nigeria & & \\
\hline Tuvalu & United Kingdom & Pakistan & & \\
\hline Uruguay & United States & Panama & & \\
\hline \multirow[t]{2}{*}{ Vanatu } & Yemen & Peru & & \\
\hline & Yugoslavia & Philippines & & \\
\hline
\end{tabular}


Table 5. Legislative, Economic, Demographic and Labor Force Characteristics

\begin{tabular}{|c|c|c|c|c|c|}
\hline & $\begin{array}{l}\text { Non } \\
(19 \%)\end{array}$ & $\begin{array}{l}\text { Host } \\
(25 \%)\end{array}$ & $\begin{array}{l}\text { Hub } \\
(38 \%)\end{array}$ & $\begin{array}{l}\text { Source } \\
(18 \%) \\
\end{array}$ & $\begin{array}{l}\text { All } \\
(100 \%)\end{array}$ \\
\hline Grants Legal Status/Amnesty to trafficked victims & $0.0 \%$ & $22.2 \%$ & $6.2 \%$ & $0.0 \%$ & $7.6 \%$ \\
\hline Prohibits prostitution & $39.0 \%$ & $35.6 \%$ & $41.5 \%$ & $34.4 \%$ & $38.3 \%$ \\
\hline Employment in $\mathrm{Ag}(\%$ of total) & 12.58 & 5.53 & 26.90 & 25.10 & 17.90 \\
\hline Population Density (people per sq) & 167.41 & 279.98 & 119.88 & 55.37 & 156.52 \\
\hline Mortality Rate (under 5 per 1000) & 41.68 & 36.90 & 80.73 & 96.69 & 64.74 \\
\hline Literacy Rate (\% of population) & 84.90 & 82.17 & 77.42 & 77.28 & 79.32 \\
\hline Female Unemployment Rate & 13.84 & 7.55 & 11.15 & 11.93 & 10.24 \\
\hline $\begin{array}{l}\text { Male Unemployment Rate } \\
\text { Log GDP per capita in constant } 1995 \text { USD } \\
\text { (std. dev.) } \\
\text { Political Stability } \\
\text { (std. dev.) } \\
\text { Voice and accountability } \\
\text { (std. dev.) } \\
\text { Rule of law } \\
\text { (std. dev.) }\end{array}$ & $\begin{array}{l}9.26 \\
7.80 \\
(1.35) \\
0.372 \\
(0.658) \\
0.245 \\
(0.897) \\
0.252 \\
(0.802)\end{array}$ & $\begin{array}{l}5.95 \\
9.04 \\
(1.54) \\
0.539 \\
(0.925) \\
0.487 \\
(1.042) \\
0.728 \\
(0.945)\end{array}$ & $\begin{array}{l}9.43 \\
7.03 \\
(1.21) \\
-0.279 \\
(0.796) \\
-0.251 \\
(0.835) \\
-0.327 \\
(0.695)\end{array}$ & $\begin{array}{l}11.25 \\
6.51 \\
(1.08) \\
-0.486 \\
(0.854) \\
-0.285 \\
(0.790) \\
-0.468 \\
(0.625)\end{array}$ & $\begin{array}{l}8.38 \\
7.61 \\
(1.59) \\
-0.012 \\
(0.927) \\
0.014 \\
(0.955) \\
0.006 \\
(0.912)\end{array}$ \\
\hline Legal origins - French & $40.0 \%$ & $46.5 \%$ & $42.6 \%$ & $45.1 \%$ & $43.6 \%$ \\
\hline Legal origins - German & $0.0 \%$ & $9.3 \%$ & $1.6 \%$ & $0.0 \%$ & $3.03 \%$ \\
\hline Legal origins - British & $53.3 \%$ & $32.5 \%$ & $27.8 \%$ & $25.8 \%$ & $33.3 \%$ \\
\hline Legal origins - Socialist & $0.0 \%$ & $2.3 \%$ & $27.8 \%$ & $29.0 \%$ & $17.0 \%$ \\
\hline $\begin{array}{l}\text { Legal origins - Scandinavian } \\
\text { Distaste for foreign neighbors } \\
\text { (std. dev.) } \\
\text { Justifiability of prostitution } \\
\text { (std. dev.) } \\
\text { Settler mortality } \\
\text { (std. dev.) }\end{array}$ & $\begin{array}{l}3.3 \% \\
0.135 \\
(0.123) \\
3.03 \\
(1.045) \\
62.57 \\
(38.05) \\
\end{array}$ & $\begin{array}{l}9.3 \% \\
0.122 \\
(0.071) \\
3.243 \\
(0.961) \\
209.8 \\
(392.51) \\
\end{array}$ & $\begin{array}{l}0.0 \% \\
0.222 \\
(0.102) \\
2.101 \\
(0.686) \\
300.27 \\
(585.71) \\
\end{array}$ & $\begin{array}{l}0.0 \% \\
0.169 \\
(0.0422) \\
2.283 \\
(0.607) \\
170.93 \\
(158.42) \\
\end{array}$ & $\begin{array}{l}3.03 \% \\
0.175 \\
(0.100) \\
2.529 \\
(0.948) \\
223.49 \\
(449.36) \\
\end{array}$ \\
\hline
\end{tabular}


Table 6

Probability of Trafficking - Probit Marginal Effect Estimates

\begin{tabular}{|c|c|c|c|c|c|c|}
\hline VARIABLES & (1) & (2) & (3) & (4) & (5) & (6) \\
\hline \multirow{2}{*}{ Host country grants amnesty } & $0.057 * *$ & $0.011^{* *}$ & $0.011 * *$ & $0.0077 * * *$ & $0.015^{* *}$ & $0.0096^{* * *}$ \\
\hline & $(0.027)$ & $(0.0044)$ & $(0.0050)$ & $(0.0026)$ & $(0.0070)$ & $(0.0031)$ \\
\hline \multirow{2}{*}{ Host country prostitution laws } & 0.0015 & 0.0012 & 0.00084 & 0.00035 & 0.00022 & 0.000080 \\
\hline & $(0.0054)$ & $(0.0022)$ & (0.0019) & (0.00085) & (0.0019) & $(0.00090)$ \\
\hline \multirow[t]{2}{*}{ Host country log GDP per capita } & & $0.0037^{*}$ & $0.0025^{*}$ & $0.0013^{* * *}$ & $0.0036^{* *}$ & $0.0016^{* * *}$ \\
\hline & & (0.0019) & $(0.0015)$ & $(0.00043)$ & $(0.0017)$ & $(0.00042)$ \\
\hline \multirow[t]{2}{*}{ Host country is a transition economy } & & & $-0.0038^{* * *}$ & $-0.0020 * * *$ & $-0.0059 * * *$ & $-0.0027 * * *$ \\
\hline & & & $(0.0011)$ & $(0.00021)$ & $(0.0016)$ & $(0.00029)$ \\
\hline \multirow[t]{2}{*}{ Host country is land locked } & & & $-0.0027^{* *}$ & $-0.0013 * * *$ & $-0.0042^{* *}$ & $-0.0018^{* * *}$ \\
\hline & & & $(0.0010)$ & $(0.00034)$ & $(0.0019)$ & $(0.00053)$ \\
\hline \multirow[t]{2}{*}{ Source country prostitution laws } & 0.0049 & 0.0030 & 0.0018 & 0.00071 & 0.0029 & 0.0012 \\
\hline & $(0.0062)$ & $(0.0034)$ & $(0.0024)$ & $(0.00073)$ & (0.0038) & (0.00081) \\
\hline \multirow[t]{2}{*}{ Source country log GDP per capita } & & $-0.0029 *$ & $-0.0029 * *$ & $-0.0013 * * *$ & $-0.0030 *$ & $-0.00097 * *$ \\
\hline & & $(0.0015)$ & $(0.0014)$ & $(0.00032)$ & $(0.0016)$ & $(0.00049)$ \\
\hline \multirow[t]{2}{*}{ Source country is a transition economy } & & & $0.017 * * *$ & $0.028 * * *$ & $0.017 * * *$ & $0.046 * *$ \\
\hline & & & $(0.0048)$ & $(0.0077)$ & $(0.0057)$ & $(0.023)$ \\
\hline \multirow{2}{*}{ Source country is land locked } & & & -0.0030 & $-0.0014^{* *}$ & -0.0041 & -0.0014 \\
\hline & & & (0.0019) & $(0.00064)$ & $(0.0032)$ & (0.00089) \\
\hline \multirow{2}{*}{ Host and source are in the same region } & & 0.0042 & 0.0070 & $0.0026^{* *}$ & 0.0093 & $0.0030 *$ \\
\hline & & $(0.0054)$ & $(0.0043)$ & $(0.0013)$ & $(0.0064)$ & (0.0018) \\
\hline \multirow[t]{2}{*}{ Host and source share a border } & & $0.041 *$ & 0.039 & $0.026^{*}$ & $0.038^{*}$ & $0.022 * * *$ \\
\hline & & $(0.023)$ & $(0.025)$ & $(0.014)$ & $(0.020)$ & $(0.0084)$ \\
\hline \multirow[t]{2}{*}{ Distance ('000 km) } & & $-0.0016^{* *}$ & $-0.00098^{* * *}$ & $-0.00072^{* * *}$ & $-0.0014^{* * *}$ & $-0.00099 * * *$ \\
\hline & & $(0.00064)$ & $(0.00024)$ & $(0.000098)$ & $(0.00037)$ & $(0.00015)$ \\
\hline \multirow[t]{2}{*}{ Source country lies in EAP } & & & & $0.15^{* * *}$ & & $0.26 * * *$ \\
\hline & & & & $(0.018)$ & & $(0.053)$ \\
\hline \multirow[t]{2}{*}{ Source country lies in ECA } & & & & $0.017 * * *$ & & $0.011 * *$ \\
\hline & & & & $(0.0037)$ & & $(0.0051)$ \\
\hline \multirow[t]{2}{*}{ Source country lies in MENA } & & & & $0.0080 * * *$ & & 0.0060 \\
\hline & & & & $(0.0025)$ & & $(0.0038)$ \\
\hline \multirow[t]{2}{*}{ Source country lies in South Asia } & & & & $0.13 * * *$ & & $0.16^{* * *}$ \\
\hline & & & & $(0.022)$ & & $(0.049)$ \\
\hline \multirow[t]{2}{*}{ Source country lies in SSA } & & & & $0.029 * * *$ & & $0.037 * * *$ \\
\hline & & & & $(0.0078)$ & & $(0.014)$ \\
\hline \multirow[t]{2}{*}{ Source country lies in LAC } & & & & $0.059 * * *$ & & $0.084 * * *$ \\
\hline & & & & $(0.011)$ & & $(0.022)$ \\
\hline \multirow[t]{2}{*}{ Host country political stability } & & & & & -0.00094 & $-0.00073 * *$ \\
\hline & & & & & $(0.00093)$ & $(0.00030)$ \\
\hline \multirow[t]{2}{*}{ Host country voice and accountability } & & & & & -0.00093 & -0.00029 \\
\hline & & & & & $(0.0017)$ & $(0.00063)$ \\
\hline Host country rule of law & & & & & 0.00087 & 0.00055 \\
\hline & & & & & $(0.0025)$ & $(0.00095)$ \\
\hline Source country political stability & & & & & 0.00083 & $-0.0015^{*}$ \\
\hline & & & & & $(0.0027)$ & $(0.00089)$ \\
\hline Source country voice and accountability & & & & & 0.00059 & -0.00018 \\
\hline & & & & & $(0.0022)$ & $(0.00069)$ \\
\hline Source country rule of law & & & & & $-0.0042^{*}$ & 0.000063 \\
\hline & & & & & $(0.0024)$ & $(0.0016)$ \\
\hline Observations & 30,940 & 26,560 & 26,560 & 26,560 & 18,358 & 18,358 \\
\hline Pseudo R-squared & 0.043 & 0.22 & 0.26 & 0.30 & 0.25 & 0.31 \\
\hline Log likelihood & -2757 & -2081 & -1975 & -1866 & -1734 & -1604 \\
\hline
\end{tabular}

Notes: a) Standard errors in parentheses allow for inter-regional correlations b) ${ }^{* * *} \mathrm{p}<0.01,{ }^{* *} \mathrm{p}<0.05,{ }^{*} \mathrm{p}<0.1$ 
Table 7a

Instrumental variable estimates of the probability of trafficking - Selected marginal effects

\begin{tabular}{lcccccc}
\multicolumn{7}{c}{ (standard errors) } \\
\hline VARIABLES & $(1)$ & $(2)$ & $(3)$ & $(4)$ & $(5)$ & $(6)$ \\
Host country grants amnesty & 0.23 & 0.010 & 0.022 & 0.017 & 0.033 & 0.027 \\
& $(0.15)$ & $(0.012)$ & $(0.018)$ & $(0.012)$ & $(0.023)$ & $(0.020)$ \\
Host country prostitution laws & 0.0053 & 0.0010 & 0.0015 & 0.00074 & 0.0015 & 0.00072 \\
& $(0.0060)$ & $(0.0026)$ & $(0.0022)$ & $(0.00087)$ & $(0.0018)$ & $(0.00067)$ \\
Source country prostitution laws & 0.0078 & 0.0046 & 0.0024 & 0.0010 & 0.0023 & 0.00088 \\
& $(0.0096)$ & $(0.0054)$ & $(0.0033)$ & $(0.00068)$ & $(0.0030)$ & $(0.00055)$ \\
Generalized residual & -0.034 & 0.0015 & -0.0019 & -0.0013 & -0.0034 & -0.0021 \\
& $(0.021)$ & $(0.0035)$ & $(0.0028)$ & $(0.0013)$ & $(0.0027)$ & $(0.0014)$ \\
Observations & 17,293 & 17,293 & 17,293 & 17,293 & 17,293 & 17,293 \\
\hline
\end{tabular}

Notes: a) Standard errors allow for intra-regional correlations b) Legal origin is used as an instrumental variable c) The full set of regressors in each of the six specifications is the same as those reported in columns 1 to 6 of Table $6 \mathrm{~d}$ ) ${ }^{* * *} \mathrm{p}<0.01,{ }^{* *} \mathrm{p}<0.05,{ }^{*} \mathrm{p}<0.1$.

Table $7 b$

Instrumental variable estimates of the probability of trafficking - Selected marginal effects

\begin{tabular}{lcccccc}
\multicolumn{7}{c}{ (standard errors) } \\
\hline VARIABLES & $(1)$ & $(2)$ & $(3)$ & $(4)$ & $(5)$ & $(6)$ \\
Host country grants amnesty & $0.13^{* * *}$ & $0.047^{*}$ & $0.054^{*}$ & $0.0076^{* *}$ & $0.055^{*}$ & 0.0067 \\
& $(0.045)$ & $(0.026)$ & $(0.029)$ & $(0.0037)$ & $(0.031)$ & $(0.0045)$ \\
Host country prostitution laws & $0.012^{* *}$ & 0.0052 & 0.0045 & $0.00028^{* *}$ & 0.0043 & $0.00026^{* * *}$ \\
& $(0.0059)$ & $(0.0036)$ & $(0.0032)$ & $(0.00014)$ & $(0.0031)$ & $(0.000095)$ \\
Source country prostitution laws & 0.0048 & 0.0048 & 0.0030 & $0.00014^{*}$ & 0.0028 & $0.00015^{* * *}$ \\
& $(0.0071)$ & $(0.0042)$ & $(0.0031)$ & $(0.000082)$ & $(0.0027)$ & $(0.000045)$ \\
Generalized residual & $-0.019^{* * *}$ & -0.0037 & -0.0040 & -0.00016 & -0.0040 & -0.00014 \\
& $(0.0067)$ & $(0.0033)$ & $(0.0030)$ & $(0.00017)$ & $(0.0031)$ & $(0.00018)$ \\
Observations & 8,905 & 8,905 & 8,905 & 8,905 & 8,905 & 8,905 \\
\hline
\end{tabular}

Notes: a) Standard errors allow for intra-regional correlations b) Settler mortality is used as an instrumental variable c) The full set of regressors in each of the six specifications is the same as those reported in columns 1 to 6 of Table $6 \mathrm{~d}){ }^{* * *} \mathrm{p}<0.01,{ }^{* *} \mathrm{p}<0.05,{ }^{*} \mathrm{p}<0.1$

Table 7c

Instrumental variable estimates of the probability of trafficking - Selected marginal effects

\begin{tabular}{lcccccc}
\multicolumn{7}{c}{ (standard errors) } \\
\hline VARIABLES & $(1)$ & $(2)$ & $(3)$ & $(4)$ & $(5)$ & $(6)$ \\
Host country grants amnesty & $0.13^{* * *}$ & $0.077^{* *}$ & $0.081^{* *}$ & $0.013^{* *}$ & $0.081^{*}$ & $0.012^{*}$ \\
& $(0.051)$ & $(0.037)$ & $(0.040)$ & $(0.0062)$ & $(0.043)$ & $(0.0062)$ \\
Host country prostitution laws & $0.012^{* *}$ & 0.0056 & 0.0046 & $0.00031^{* *}$ & 0.0044 & $0.00027^{* * *}$ \\
& $(0.0058)$ & $(0.0039)$ & $(0.0033)$ & $(0.00015)$ & $(0.0033)$ & $(0.000088)$ \\
Source country prostitution laws & 0.0048 & 0.0047 & 0.0029 & $0.00014^{*}$ & 0.0027 & $0.00015^{* * *}$ \\
& $(0.0070)$ & $(0.0041)$ & $(0.0029)$ & $(0.000079)$ & $(0.0026)$ & $(0.000040)$ \\
Generalized residual & $-0.024^{* *}$ & $-0.0085^{*}$ & $-0.0074^{*}$ & $-0.00036^{*}$ & -0.0072 & $-0.00030^{*}$ \\
& $(0.0097)$ & $(0.0050)$ & $(0.0044)$ & $(0.00022)$ & $(0.0046)$ & $(0.00018)$ \\
Observations & 8,905 & 8,905 & 8,905 & 8,905 & 8,905 & 8,905 \\
\hline
\end{tabular}

Notes: a) Standard errors allow for intra-regional correlations b) Legal origin and settler mortality are used as instrumental variables c) The full set of regressors in each of the six specifications is the same as those reported in columns 1 to 6 of Table $6 \mathrm{~d}){ }^{* * *} \mathrm{p}<0.01$, ** $\mathrm{p}<0.05$, * $\mathrm{p}<0.1$ 


\section{Appendix Table 1 \\ Probability of Trafficking - Probit Marginal Effect Estimates Including Host Country Values}

\begin{tabular}{|c|c|c|c|c|c|}
\hline VARIABLES & (1) & (2) & (3) & (4) & $(5)$ \\
\hline \multirow[t]{2}{*}{ Host country grants amnesty } & $0.0077 * * *$ & $0.0075^{* * *}$ & $0.017 * * *$ & $0.0043 * * *$ & $0.0039 * * *$ \\
\hline & $(0.0026)$ & $(0.0029)$ & $(0.0049)$ & $(0.0016)$ & $(0.0015)$ \\
\hline \multirow[t]{2}{*}{ Host country prostitution laws } & 0.00035 & 0.00065 & 0.00016 & 0.00022 & 0.00018 \\
\hline & $(0.00085)$ & $(0.00079)$ & $(0.0017)$ & $(0.00020)$ & $(0.00016)$ \\
\hline \multirow[t]{2}{*}{ Host country log GDP per capita } & $0.0013 * * *$ & $0.00099 * * *$ & $0.0013 * * *$ & $0.00015^{* * *}$ & $0.00015^{* * *}$ \\
\hline & $(0.00043)$ & $(0.00026)$ & $(0.00039)$ & $(0.000036)$ & $(0.000031)$ \\
\hline \multirow[t]{2}{*}{ Host country is a transition economy } & $-0.0020 * * *$ & $-0.0021 * * *$ & $-0.0057 * * *$ & & \\
\hline & $(0.00021)$ & $(0.00047)$ & $(0.00078)$ & & \\
\hline \multirow[t]{2}{*}{ Host country is land locked } & $-0.0013^{* * *}$ & $-0.0018^{* * *}$ & $-0.0024 * * *$ & $-0.00023^{*}$ & -0.00019 \\
\hline & $(0.00034)$ & $(0.00053)$ & $(0.00044)$ & $(0.00013)$ & $(0.00013)$ \\
\hline \multirow[t]{2}{*}{ Source country prostitution laws } & 0.00071 & 0.00053 & 0.0014 & 0.00012 & 0.00012 \\
\hline & $(0.00073)$ & $(0.00053)$ & $(0.0014)$ & $(0.00011)$ & $(0.00011)$ \\
\hline \multirow[t]{2}{*}{ Source country log GDP per capita } & $-0.0013^{* * *}$ & $-0.0011 * * *$ & $-0.0016 * * *$ & $-0.00023 * * *$ & $-0.00024 * * *$ \\
\hline & $(0.00032)$ & $(0.00032)$ & $(0.00020)$ & $(0.000051)$ & $(0.000049)$ \\
\hline \multirow[t]{2}{*}{ Source country is a transition economy } & $0.028^{* * *}$ & $0.026^{* * *}$ & $0.024 * * *$ & $0.81 * * *$ & $0.81 * * *$ \\
\hline & $(0.0077)$ & $(0.0067)$ & $(0.0040)$ & $(0.019)$ & $(0.018)$ \\
\hline \multirow[t]{2}{*}{ Source country is land locked } & $-0.0014 * *$ & $-0.0012 * *$ & $-0.0016^{* * *}$ & $-0.00027 * * *$ & $-0.00027 * * *$ \\
\hline & $(0.00064)$ & $(0.00051)$ & $(0.00048)$ & $(0.000092)$ & $(0.000090)$ \\
\hline \multirow[t]{2}{*}{ Host and source are in the same region } & $0.0026^{* *}$ & $0.0029 *$ & $0.0054 * *$ & $0.0014^{* *}$ & $0.0013^{* *}$ \\
\hline & $(0.0013)$ & $(0.0015)$ & $(0.0025)$ & $(0.00060)$ & $(0.00050)$ \\
\hline \multirow[t]{2}{*}{ Host and source share a border } & $0.026^{*}$ & $0.027 * *$ & $0.028^{* * *}$ & 0.0077 & 0.0078 \\
\hline & $(0.014)$ & $(0.014)$ & $(0.0091)$ & $(0.0052)$ & $(0.0057)$ \\
\hline \multirow[t]{2}{*}{ Distance ('000 km) } & $-0.00072 * * *$ & $-0.00062^{* * *}$ & $-0.00090^{* * *}$ & $-0.000086^{* * *}$ & $-0.000088^{* * *}$ \\
\hline & $(0.000098)$ & $(0.00014)$ & $(0.00016)$ & $(0.000011)$ & $(0.000010)$ \\
\hline \multirow[t]{2}{*}{ Source country lies in EAP } & $0.15^{* * *}$ & $0.16^{* * *}$ & $0.11 * * *$ & $0.98^{* * *}$ & $0.98^{* * *}$ \\
\hline & $(0.018)$ & $(0.026)$ & $(0.021)$ & $(0.0095)$ & $(0.0095)$ \\
\hline \multirow[t]{2}{*}{ Source country lies in ECA } & $0.017 * * *$ & $0.020 * * *$ & $0.030 * * *$ & 0.0070 & $0.0061 *$ \\
\hline & $(0.0037)$ & $(0.0052)$ & $(0.0053)$ & $(0.0043)$ & $(0.0034)$ \\
\hline \multirow[t]{2}{*}{ Source country lies in MENA } & $0.0080 * * *$ & $0.0092 * * *$ & $0.011^{* *}$ & $0.91 * * *$ & $0.90^{* * *}$ \\
\hline & $(0.0025)$ & $(0.0032)$ & $(0.0044)$ & $(0.042)$ & $(0.038)$ \\
\hline \multirow[t]{2}{*}{ Source country lies in South Asia } & $0.13^{* * *}$ & $0.14^{* * *}$ & $0.11 * * *$ & $0.99 * * *$ & $0.99 * * *$ \\
\hline & $(0.022)$ & $(0.034)$ & $(0.023)$ & $(0.0042)$ & $(0.0048)$ \\
\hline \multirow[t]{2}{*}{ Source country lies in SSA } & $0.029 * * *$ & $0.031 * * *$ & $0.024 * * *$ & $0.75^{* * *}$ & $0.73 * * *$ \\
\hline & $(0.0078)$ & $(0.0098)$ & $(0.0044)$ & $(0.055)$ & $(0.056)$ \\
\hline \multirow[t]{2}{*}{ Source country lies in LAC } & $0.059 * * *$ & $0.061 * * *$ & $0.080 * * *$ & $0.90 * * *$ & $0.90 * * *$ \\
\hline & $(0.011)$ & $(0.014)$ & $(0.011)$ & $(0.036)$ & $(0.038)$ \\
\hline \multirow[t]{2}{*}{ Host country has French legal origin } & & -0.00024 & & & $-0.00028^{*}$ \\
\hline & & $(0.00043)$ & & & $(0.00016)$ \\
\hline \multirow[t]{2}{*}{ Host country has German legal origin } & & 0.0022 & & & \\
\hline & & $(0.0019)$ & & & \\
\hline \multirow[t]{2}{*}{ Host country distaste for foreign neighbors } & & & 0.0068 & & \\
\hline & & & $(0.0059)$ & & \\
\hline Host country - justifiability of prostitution & & & -0.00021 & & \\
\hline & & & $(0.00044)$ & & \\
\hline Mortality & & & & $3.2 \mathrm{e}-07 * * *$ & $3.0 \mathrm{e}-07 * * *$ \\
\hline & & & & $(1.0 \mathrm{e}-07)$ & $(9.2 \mathrm{e}-08)$ \\
\hline Observations & 26,560 & 24,649 & 10,458 & 11,620 & 11,620 \\
\hline Pseudo R-squared & 0.30 & 0.31 & 0.32 & 0.31 & 0.32 \\
\hline Log likelihood & -1866 & -1747 & -903 & -690 & -685 \\
\hline
\end{tabular}

Notes: a) Standard errors in parentheses allow for intra-regional correlation $\mathrm{b})^{* * *} \mathrm{p}<0.01,{ }^{* *} \mathrm{p}<0.05,{ }^{*} \mathrm{p}<0.1$ 


\section{Appendix Table 2 \\ Probability of Trafficking - Probit Marginal Effect Estimates \\ Excluding East Africa}

\begin{tabular}{|c|c|c|c|c|c|c|}
\hline VARIABLES & (1) & (2) & (3) & (4) & (5) & (6) \\
\hline \multirow{2}{*}{ Host country grants amnesty } & $0.059 * *$ & $0.011 * *$ & $0.011^{* *}$ & $0.0078^{* * *}$ & $0.016^{* *}$ & $0.0095^{* * *}$ \\
\hline & $(0.028)$ & $(0.0043)$ & $(0.0052)$ & $(0.0028)$ & $(0.0072)$ & $(0.0032)$ \\
\hline \multirow{2}{*}{ Host country prostitution laws } & 0.0013 & 0.0011 & 0.00075 & 0.00031 & 0.00022 & 0.000078 \\
\hline & $(0.0057)$ & $(0.0021)$ & $(0.0019)$ & $(0.00084)$ & $(0.0020)$ & $(0.00088)$ \\
\hline \multirow[t]{2}{*}{ Host country log GDP per capita } & & $0.0036^{* *}$ & $0.0024^{*}$ & $0.0012^{* * *}$ & $0.0035^{* *}$ & $0.0015^{* * *}$ \\
\hline & & $(0.0018)$ & $(0.0015)$ & $(0.00046)$ & $(0.0017)$ & $(0.00046)$ \\
\hline \multirow[t]{2}{*}{ Host country is a transition economy } & & & $-0.0039 * * *$ & $-0.0020 * * *$ & $-0.0061^{* * *}$ & $-0.0028^{* * *}$ \\
\hline & & & $(0.0011)$ & $(0.00025)$ & $(0.0017)$ & $(0.00030)$ \\
\hline \multirow[t]{2}{*}{ Host country is land locked } & & & $-0.0026^{* * *}$ & $-0.0013^{* * *}$ & $-0.0043^{* *}$ & $-0.0018^{* * *}$ \\
\hline & & & $(0.0010)$ & $(0.00036)$ & $(0.0020)$ & $(0.00053)$ \\
\hline \multirow[t]{2}{*}{ Source country prostitution laws } & 0.0056 & 0.0033 & 0.0020 & 0.00086 & 0.0026 & 0.0011 \\
\hline & $(0.0064)$ & $(0.0034)$ & $(0.0024)$ & $(0.00062)$ & $(0.0036)$ & $(0.00081)$ \\
\hline \multirow[t]{2}{*}{ Source country log GDP per capita } & & $-0.0032 * *$ & $-0.0030 * *$ & $-0.0012^{* * *}$ & $-0.0033^{*}$ & -0.00093 \\
\hline & & $(0.0014)$ & $(0.0014)$ & $(0.00036)$ & $(0.0020)$ & $(0.00057)$ \\
\hline \multirow[t]{2}{*}{ Source country is a transition economy } & & & $0.015^{* * *}$ & $0.025^{* * *}$ & $0.017 * * *$ & $0.044^{*}$ \\
\hline & & & $(0.0045)$ & $(0.0080)$ & $(0.0062)$ & $(0.023)$ \\
\hline \multirow{2}{*}{ Source country is land locked } & & & -0.0027 & $-0.0013^{* *}$ & -0.0042 & -0.0012 \\
\hline & & & $(0.0017)$ & (0.00064) & $(0.0035)$ & $(0.00093)$ \\
\hline \multirow{2}{*}{ Host and source are in the same region } & & 0.0046 & $0.0076^{*}$ & $0.0030^{*}$ & 0.010 & 0.0035 \\
\hline & & $(0.0057)$ & $(0.0046)$ & $(0.0017)$ & $(0.0073)$ & $(0.0023)$ \\
\hline \multirow[t]{2}{*}{ Host and source share a border } & & $0.040^{*}$ & 0.038 & $0.026^{*}$ & $0.038^{*}$ & $0.021 * *$ \\
\hline & & $(0.022)$ & $(0.024)$ & $(0.014)$ & $(0.020)$ & $(0.0086)$ \\
\hline \multirow[t]{2}{*}{ Distance ('000 km) } & & $-0.0015^{* *}$ & $-0.00094^{* * *}$ & $-0.00067 * * *$ & $-0.0014^{* * *}$ & $-0.00092^{* * *}$ \\
\hline & & $(0.00063)$ & $(0.00025)$ & $(0.00011)$ & $(0.00039)$ & $(0.00018)$ \\
\hline \multirow[t]{2}{*}{ Source country lies in EAP } & & & & $0.14 * * *$ & & $0.26 * * *$ \\
\hline & & & & $(0.019)$ & & $(0.055)$ \\
\hline \multirow[t]{2}{*}{ Source country lies in ECA } & & & & $0.017 * * *$ & & $0.011^{* *}$ \\
\hline & & & & $(0.0037)$ & & $(0.0055)$ \\
\hline \multirow[t]{2}{*}{ Source country lies in MENA } & & & & $0.0076^{* * *}$ & & 0.0063 \\
\hline & & & & $(0.0025)$ & & $(0.0041)$ \\
\hline \multirow[t]{2}{*}{ Source country lies in South Asia } & & & & $0.12 * * *$ & & $0.16^{* * *}$ \\
\hline & & & & $(0.024)$ & & $(0.053)$ \\
\hline \multirow[t]{2}{*}{ Source country lies in SSA } & & & & $0.034 * * *$ & & $0.041 * * *$ \\
\hline & & & & $(0.011)$ & & $(0.015)$ \\
\hline \multirow[t]{2}{*}{ Source country lies in LAC } & & & & $0.055^{* * *}$ & & $0.082 * * *$ \\
\hline & & & & $(0.012)$ & & $(0.022)$ \\
\hline \multirow[t]{2}{*}{ Host country political stability } & & & & & -0.0011 & $-0.00077 * *$ \\
\hline & & & & & $(0.00097)$ & $(0.00032)$ \\
\hline \multirow[t]{2}{*}{ Host country voice and accountability } & & & & & -0.00062 & -0.00012 \\
\hline & & & & & $(0.0016)$ & $(0.00063)$ \\
\hline Host country rule of law & & & & & 0.00091 & 0.00054 \\
\hline & & & & & $(0.0026)$ & $(0.00096)$ \\
\hline Source country political stability & & & & & 0.00065 & $-0.0015^{*}$ \\
\hline & & & & & $(0.0026)$ & $(0.00090)$ \\
\hline Source country voice and accountability & & & & & 0.00060 & -0.00018 \\
\hline & & & & & $(0.0021)$ & $(0.00069)$ \\
\hline Source country rule of law & & & & & -0.0036 & 0.00017 \\
\hline & & & & & $(0.0028)$ & $(0.0018)$ \\
\hline Observations & 29,484 & 25,232 & 25,232 & 25,232 & 17,673 & 17,673 \\
\hline Pseudo R-squared & 0.044 & 0.23 & 0.26 & 0.30 & 0.25 & 0.31 \\
\hline Log likelihood & -2685 & -2006 & -1908 & -1808 & -1686 & -1557 \\
\hline
\end{tabular}




\section{Appendix Table 3 \\ Probability of Trafficking - Probit Marginal Effect Estimates Excluding West and Central Africa}

\begin{tabular}{|c|c|c|c|c|c|c|}
\hline VARIABLES & (1) & (2) & (3) & (4) & (5) & (6) \\
\hline \multirow[t]{2}{*}{ Host country grants amnesty } & $0.057 *$ & $0.0088^{* *}$ & $0.0091 * *$ & $0.0060 * * *$ & $0.013^{* *}$ & $0.0078^{* * *}$ \\
\hline & $(0.029)$ & $(0.0040)$ & $(0.0041)$ & $(0.0016)$ & $(0.0057)$ & $(0.0020)$ \\
\hline \multirow{2}{*}{ Host country prostitution laws } & 0.0016 & 0.0013 & 0.00096 & 0.00042 & 0.00023 & 0.000072 \\
\hline & $(0.0059)$ & $(0.0023)$ & $(0.0022)$ & $(0.00097)$ & $(0.0022)$ & $(0.0010)$ \\
\hline \multirow[t]{2}{*}{ Host country log GDP per capita } & & $0.0038^{* *}$ & $0.0028^{* *}$ & $0.0014 * * *$ & $0.0043 * * *$ & $0.0019 * * *$ \\
\hline & & $(0.0016)$ & $(0.0013)$ & $(0.00023)$ & $(0.0016)$ & $(0.00029)$ \\
\hline \multirow[t]{2}{*}{ Host country is a transition economy } & & & $-0.0031 * * *$ & $-0.0016 * * *$ & $-0.0048^{* * *}$ & $-0.0021 * * *$ \\
\hline & & & $(0.00085)$ & $(0.00030)$ & $(0.0014)$ & $(0.00047)$ \\
\hline \multirow[t]{2}{*}{ Host country is land locked } & & & $-0.0023^{* *}$ & $-0.0010^{*}$ & $-0.0035^{*}$ & $-0.0014 * *$ \\
\hline & & & $(0.0011)$ & $(0.00053)$ & $(0.0020)$ & $(0.00072)$ \\
\hline \multirow[t]{2}{*}{ Source country prostitution laws } & 0.0060 & 0.0031 & 0.0020 & 0.00086 & 0.0034 & $0.0014^{* *}$ \\
\hline & $(0.0064)$ & $(0.0034)$ & $(0.0025)$ & $(0.00058)$ & $(0.0040)$ & $(0.00063)$ \\
\hline \multirow[t]{2}{*}{ Source country log GDP per capita } & & $-0.0028^{*}$ & $-0.0027 * *$ & $-0.0010 * * *$ & $-0.0029 *$ & $-0.00072 *$ \\
\hline & & $(0.0014)$ & $(0.0013)$ & $(0.00022)$ & $(0.0017)$ & $(0.00039)$ \\
\hline \multirow[t]{2}{*}{ Source country is a transition economy } & & & $0.014 * * *$ & $0.025^{* * *}$ & $0.013 * * *$ & $0.036^{*}$ \\
\hline & & & $(0.0046)$ & $(0.0059)$ & $(0.0048)$ & $(0.020)$ \\
\hline \multirow[t]{2}{*}{ Source country is land locked } & & & -0.0025 & $-0.00099 * *$ & -0.0033 & -0.00086 \\
\hline & & & $(0.0017)$ & $(0.00048)$ & $(0.0030)$ & $(0.00082)$ \\
\hline \multirow[t]{2}{*}{ Host and source are in the same region } & & 0.0016 & 0.0045 & 0.0012 & 0.0055 & 0.0012 \\
\hline & & $(0.0038)$ & $(0.0034)$ & $(0.00086)$ & $(0.0050)$ & $(0.0012)$ \\
\hline \multirow[t]{2}{*}{ Host and source share a border } & & $0.040 * *$ & $0.039 *$ & $0.027 * *$ & $0.037 * *$ & $0.021 * * *$ \\
\hline & & $(0.020)$ & $(0.023)$ & $(0.012)$ & $(0.017)$ & $(0.0061)$ \\
\hline \multirow[t]{2}{*}{ Distance ('000 km) } & & $-0.0014 * *$ & $-0.00089 * * *$ & $-0.00064 * * *$ & $-0.0014 * * *$ & $-0.00093 * * *$ \\
\hline & & $(0.00059)$ & $(0.00025)$ & $(0.00011)$ & $(0.00039)$ & $(0.00016)$ \\
\hline \multirow[t]{2}{*}{ Source country lies in EAP } & & & & $0.14^{* * *}$ & & $0.23^{* * *}$ \\
\hline & & & & $(0.019)$ & & $(0.053)$ \\
\hline \multirow[t]{2}{*}{ Source country lies in ECA } & & & & $0.014^{* * *}$ & & $0.0098^{*}$ \\
\hline & & & & $(0.0027)$ & & $(0.0056)$ \\
\hline \multirow[t]{2}{*}{ Source country lies in MENA } & & & & $0.0070 * * *$ & & 0.0055 \\
\hline & & & & $(0.0024)$ & & $(0.0039)$ \\
\hline \multirow[t]{2}{*}{ Source country lies in South Asia } & & & & $0.12^{* * *}$ & & $0.15^{* * *}$ \\
\hline & & & & $(0.018)$ & & $(0.045)$ \\
\hline \multirow[t]{2}{*}{ Source country lies in SSA } & & & & $0.028^{* * *}$ & & $0.041^{* * *}$ \\
\hline & & & & $(0.0047)$ & & $(0.014)$ \\
\hline \multirow[t]{2}{*}{ Source country lies in LAC } & & & & $0.055^{* * *}$ & & $0.077 * * *$ \\
\hline & & & & $(0.0061)$ & & $(0.019)$ \\
\hline \multirow[t]{2}{*}{ Host country political stability } & & & & & -0.0012 & $-0.00086^{*}$ \\
\hline & & & & & $(0.0012)$ & $(0.00050)$ \\
\hline \multirow[t]{2}{*}{ Host country voice and accountability } & & & & & -0.00091 & -0.00026 \\
\hline & & & & & $(0.0017)$ & $(0.00064)$ \\
\hline Host country rule of law & & & & & 0.00075 & 0.00047 \\
\hline & & & & & $(0.0027)$ & $(0.00095)$ \\
\hline Source country political stability & & & & & 0.0020 & -0.00100 \\
\hline & & & & & $(0.0030)$ & $(0.00093)$ \\
\hline Source country voice and accountability & & & & & 0.00059 & -0.00016 \\
\hline & & & & & $(0.0028)$ & $(0.00089)$ \\
\hline Source country rule of law & & & & & $-0.0052^{* * *}$ & -0.00041 \\
\hline & & & & & $(0.0019)$ & $(0.0017)$ \\
\hline Observations & 28,210 & 24,070 & 24,070 & 24,070 & 16,440 & 16,440 \\
\hline Pseudo R-squared & 0.048 & 0.23 & 0.26 & 0.31 & 0.25 & 0.31 \\
\hline Log likelihood & -2419 & -1811 & -1728 & -1617 & -1527 & -1404 \\
\hline
\end{tabular}




\section{Appendix Table 4 \\ Probability of Trafficking - Probit Marginal Effect Estimates Excluding West, Central and East Africa}

\begin{tabular}{|c|c|c|c|c|c|c|}
\hline VARIABLES & (1) & (2) & (3) & (4) & (5) & (6) \\
\hline \multirow[t]{2}{*}{ Host country grants amnesty } & $0.060 * *$ & $0.0089 * *$ & $0.0093^{* *}$ & $0.0060 * * *$ & $0.013^{* *}$ & $0.0076^{* * *}$ \\
\hline & $(0.030)$ & $(0.0038)$ & $(0.0041)$ & $(0.0017)$ & $(0.0058)$ & $(0.0021)$ \\
\hline \multirow[t]{2}{*}{ Host country prostitution laws } & 0.0013 & 0.0011 & 0.00083 & 0.00037 & 0.00021 & 0.000071 \\
\hline & $(0.0062)$ & $(0.0022)$ & $(0.0021)$ & $(0.00095)$ & $(0.0022)$ & $(0.00100)$ \\
\hline \multirow[t]{2}{*}{ Host country log GDP per capita } & & $0.0037 * * *$ & $0.0027 * *$ & $0.0013^{* * *}$ & $0.0042^{* * *}$ & $0.0018^{* * *}$ \\
\hline & & $(0.0014)$ & $(0.0013)$ & $(0.00025)$ & $(0.0016)$ & $(0.00029)$ \\
\hline \multirow[t]{2}{*}{ Host country is a transition economy } & & & $-0.0031 * * *$ & $-0.0016^{* * *}$ & $-0.0049 * * *$ & $-0.0022 * * *$ \\
\hline & & & $(0.00086)$ & $(0.00034)$ & $(0.0016)$ & $(0.00055)$ \\
\hline \multirow[t]{2}{*}{ Host country is land locked } & & & $-0.0023^{* *}$ & $-0.0010 * *$ & $-0.0036^{*}$ & $-0.0014^{* *}$ \\
\hline & & & $(0.0010)$ & $(0.00051)$ & $(0.0020)$ & $(0.00069)$ \\
\hline \multirow[t]{2}{*}{ Source country prostitution laws } & 0.0068 & 0.0033 & 0.0023 & $0.0011^{* *}$ & 0.0031 & $0.0014 * *$ \\
\hline & $(0.0068)$ & $(0.0034)$ & $(0.0024)$ & $(0.00046)$ & $(0.0036)$ & $(0.00061)$ \\
\hline \multirow[t]{2}{*}{ Source country log GDP per capita } & & $-0.0032^{* * *}$ & $-0.0029 * *$ & $-0.0010 * * *$ & -0.0032 & -0.00061 \\
\hline & & $(0.0012)$ & $(0.0013)$ & $(0.00023)$ & $(0.0022)$ & $(0.00044)$ \\
\hline \multirow[t]{2}{*}{ Source country is a transition economy } & & & $0.012^{* * *}$ & $0.021 * * *$ & $0.013^{* *}$ & $0.034^{*}$ \\
\hline & & & $(0.0040)$ & $(0.0059)$ & $(0.0051)$ & $(0.020)$ \\
\hline \multirow[t]{2}{*}{ Source country is land locked } & & & -0.0022 & -0.00081 & -0.0035 & -0.00065 \\
\hline & & & $(0.0016)$ & $(0.00054)$ & $(0.0034)$ & $(0.00091)$ \\
\hline \multirow[t]{2}{*}{ Host and source are in the same region } & & 0.0019 & 0.0049 & 0.0014 & 0.0063 & 0.0016 \\
\hline & & $(0.0038)$ & $(0.0035)$ & $(0.0011)$ & $(0.0056)$ & $(0.0016)$ \\
\hline \multirow[t]{2}{*}{ Host and source share a border } & & $0.038^{*}$ & $0.038^{*}$ & $0.026 * *$ & $0.035^{* *}$ & $0.020 * * *$ \\
\hline & & $(0.020)$ & $(0.022)$ & $(0.012)$ & $(0.017)$ & $(0.0064)$ \\
\hline \multirow[t]{2}{*}{ Distance ('000 km) } & & $-0.0013^{* *}$ & $-0.00085^{* * *}$ & $-0.00059 * * *$ & $-0.0013^{* * *}$ & $-0.00086^{* * *}$ \\
\hline & & $(0.00056)$ & $(0.00025)$ & $(0.000093)$ & $(0.00040)$ & $(0.00015)$ \\
\hline \multirow[t]{2}{*}{ Source country lies in EAP } & & & & $0.13^{* * *}$ & & $0.23 * * *$ \\
\hline & & & & $(0.016)$ & & $(0.058)$ \\
\hline \multirow[t]{2}{*}{ Source country lies in ECA } & & & & $0.015^{* * *}$ & & 0.010 \\
\hline & & & & $(0.0033)$ & & $(0.0065)$ \\
\hline \multirow[t]{2}{*}{ Source country lies in MENA } & & & & $0.0066^{* * *}$ & & 0.0059 \\
\hline & & & & $(0.0022)$ & & $(0.0045)$ \\
\hline \multirow[t]{2}{*}{ Source country lies in South Asia } & & & & $0.11 * * *$ & & $0.15^{* * *}$ \\
\hline & & & & $(0.019)$ & & $(0.053)$ \\
\hline \multirow[t]{2}{*}{ Source country lies in SSA } & & & & $0.035^{* * *}$ & & $0.045^{* * *}$ \\
\hline & & & & $(0.0064)$ & & $(0.017)$ \\
\hline \multirow[t]{2}{*}{ Source country lies in LAC } & & & & $0.052 * * *$ & & $0.074 * * *$ \\
\hline & & & & $(0.0060)$ & & $(0.020)$ \\
\hline \multirow[t]{2}{*}{ Host country political stability } & & & & & -0.0013 & -0.00088 \\
\hline & & & & & $(0.0013)$ & $(0.00054)$ \\
\hline \multirow[t]{2}{*}{ Host country voice and accountability } & & & & & -0.00055 & -0.000070 \\
\hline & & & & & $(0.0017)$ & $(0.00067)$ \\
\hline Host country rule of law & & & & & 0.00074 & 0.00043 \\
\hline & & & & & $(0.0028)$ & $(0.00094)$ \\
\hline Source country political stability & & & & & 0.0017 & -0.0010 \\
\hline & & & & & $(0.0028)$ & $(0.00090)$ \\
\hline Source country voice and accountability & & & & & 0.00055 & -0.00014 \\
\hline & & & & & $(0.0028)$ & $(0.00094)$ \\
\hline Source country rule of law & & & & & -0.0045 & -0.00043 \\
\hline & & & & & $(0.0027)$ & $(0.0019)$ \\
\hline Observations & 26,754 & 22,742 & 22,742 & 22,742 & 15,755 & 15,755 \\
\hline Pseudo R-squared & 0.050 & 0.24 & 0.27 & 0.31 & 0.26 & 0.32 \\
\hline Log likelihood & -2347 & -1733 & -1662 & -1562 & -1479 & -1358 \\
\hline
\end{tabular}


Appendix Table 5

First stage probit estimates

Host country prostitution laws

Host country log GDP per capita

Host country is a transition economy

Host country

grants amnesty

Host country Host country

\begin{tabular}{ccc} 
gants amnesty & grants amnesty & grants amnesty \\
\hline-0.068 & $-1.69^{* * *}$ & $-3.26^{* * *}$ \\
$(0.045)$ & $(0.12)$ & $(0.19)$ \\
$0.68^{* * *}$ & $1.48^{* * *}$ & $2.39^{* * *}$ \\
$(0.039)$ & $(0.11)$ & $(0.14)$
\end{tabular}

Host country is land locked

1.39 ***

(0.079)

$-0.21 * * *$

Host country political stability

$(0.060)$

$0.23 * * *$

(0.064)

Host country voice and accountability

$0.91 * * *$

$(0.059)$

Host country rule of law

-0.73 ***

Source country prostitution laws

(0.079)

$-0.0093$

(0.041)

Source country log GDP per capita

0.0048

$(0.025)$

Source country is a transition economy

0.012

$(0.21)$

Source country is land locked

0.0061

$(0.047)$

Source country political stability

$-0.0058$

(0.044)

Source country voice and accountability

$-0.00081$

(0.034)

Source country rule of law

0.0069

(0.057)

Host and source are in the same region

$-0.25^{* * *}$

(0.063)

Host and source share a border

$0.29 * *$

(0.13)

Distance ('000 km)

Source country lies in EAP

$-0.018^{* * *}$

(0.0055)

0.10

(0.095)

$-0.0085$

$(0.22)$

0.0089

(0.088)

0.038

$(0.14)$

0.027

(0.097)

0.071

Source country lies in LAC

$(0.085)$

Host country has French legal origin

$0.77 * * *$

$(0.055)$

Host country has German legal origin

$0.53 * * *$

Settler mortality

(0.068)

Constant

$-8.03 * * *$

(0.40)

$0.39 * *$

$1.08^{* * *}$

$3.02 * * *$

(0.30)

$(0.10)$

$1.94 * * *$

$-1.83^{* * *}$

(0.13)

(0.19)

$-5.49 * * *$

$-0.017$

(0.39)

$-0.023$

(0.080)

$(0.083)$

0.011

0.016

(0.048)

(0.050)

$-0.0010$

$-0.0050$

(0.42)

0.037

(0.44)

0.053

(0.093)

(0.096)

$-0.0059$

$-0.0067$

(0.086)

(0.089)

$-0.012$

$-0.018$

(0.067)

(0.069)

0.016

0.021

(0.11)

(0.11)

$-1.16^{* * *}$

$-1.32^{* * * *}$

(0.15)

(0.15)

0.19

0.16

(0.32)

(0.32)

$-0.10 * * *$

$-0.14 * * *$

(0.010)

$0.54 * * *$

(0.012)

(0.17)

$-0.0050$

$0.69 * * *$

(0.17)

$-0.019$

$(0.43)$

$(0.45)$

0.098

0.082

(0.17)

(0.18)

0.22

0.31

(0.26)

(0.27)

0.10

0.11

(0.18)

(0.19)

0.24

0.25

$(0.16)$

$(0.17)$

$-2.20 * * *$

17,293

$\begin{array}{cc}-0.045^{* * *} & -0.044^{* * *} \\ (0.0042) & (0.0042) \\ -12.0 * * * & -18.5^{* * *} \\ (1.05) & (1.25) \\ 8,905 & 8,905\end{array}$

Observations

8,905

8,905

Notes: a) Standard errors allow for intra-regional correlations. b) Standard errors in parentheses ${ }^{* * *} \mathrm{p}<0.01,{ }^{* *} \mathrm{p}<0.05,{ }^{*} \mathrm{p}<0.1$ 